УДК 624.154 .1

\title{
ОЦЕНКА НЕСУЩЕЙ СПОСОБНОСТИ СВАЙ. МЕТОДЫ РАСЧЕТА И ПРОБЛЕМАТИКА
}

\author{
Кургузов Константин Владимирович', \\ kurgusov@yandex.ru
Фоменко Игорь Константинович', ifolga@gmail.com
Сироткина Ольга Николаевна², onsirotkina@gmail.com \\ Российский государственный геологоразведочный университет им. С. Орджоникидзе, \\ Россия, 117997, г. Москва, ул. Миклхо-Маклая, 23. \\ 2 Московский государственный университет им. Ломоносова, \\ Россия, 119991, г. Москва, ГСП-1, Ленинские горы.
}

\begin{abstract}
Актуальность. Свайные фундаменты повышают надежность зданий и сооружений, снижают уровень их неравномерных деформаций. Особенно часто свайные фундаменты приходится использовать при неблагоприятных инженерно-геологических условиях строительства. При широком применении в прошлом и при высокой востребованности сегодня такого технического решения очень актуальным остается вопрос расчета и оценки несущей способности свайных фундаментов.

Цель: проведение серии аналитических расчетов по определению несущей способности свай, анализ и сравнение их результатов с данными экспериментально-полевых испытаний.

Объекты. Экспериментальные (полевые) исследования несущей способности свай выполнялись в рамках работ по проектированию и строительству жилого комплекса в Люберецком районе Московской области. В качестве исходных данных для выполнения расчетов использовались материалы проектной документации.

Методы. Для выполнения аналитических расчетов использованы методики по Нордлунду и по Томлинсону, реализованные в программных комплексах RSPile (Rocscience) и GEO5, а также эмпирический способ в соответствии с CП 24.13330.2011.

Результаты. Факторы, влияющие на несущую способность свай, имеют сложный характер взаимодействия и предопределяют комплексный механизм работы сваи в грунте, не поддающийся в настоящее время строгому математическому описанию. Выполненные сопоставительные расчеты и сравнение полученных результатов с данными статических (контрольных) испытаний забивных свай позволили сделать вывод о том, что рассмотренные методы имеют существенные расхождения в результатах оценки несущей способности. Показано, что применительно к сложным инженерно-геологическим условиям площадки строительства с присутствием в разрезе слабых пылевато-глинистых и органоминеральных грунтов, достоверность результатов расчета по методу, регламентируемому в СП 24.13330, существенно снижается.
\end{abstract}

\section{Ключевые слова:}

Расчет несущей способности свай, взаимодействие свай с грунтом, забивные сваи, висячие сваи, методы расчета свай, статические испытания свай.

\section{Введение}

Рост мегаполисов, увеличение плотности населения, глобальные экономические вызовы, градостроительные и архитектурные новации неизбежно влияют на строительный прогресс. Фактор роста нагрузок и напряжений в конструкциях, фактор сложности инженерно-геологических условий городских агломераций - все это определяет необходимость внедрения современных решений при выборе типов фундаментов.

Использование свайных фундаментов в сложных инженерно-геологических условиях требует разработки оптимальных методов расчета [1-4]. Ключевым элементом при этом является точное понимание механизма работы системы свайный фундамент - грунтовый массив. Без точных математических моделей разработка эффективного проекта строительства зданий и сооружений на свайном основании не представляется возможной. Однако любая новая модель требует апробации и верификации. Недостаточность сравнительной информации работы модели с реальным поведением системы свая - грунтовый массив заставляет проектировщиков закладывать «запасы на незнание» в проектах, что в конечном счете неизбежно приводит к существенным экономическим расходам, к увеличению сроков проектирования и строительства.

При максимальном использовании несущей способности свай по грунту и материалу обеспечивается рациональность и экономичность конструкций свайных фундаментов. К сожалению, в сложившейся отечественной практике зачастую не полностью используется прочность свай по грунту, в ряде случаев ее недоиспользование достигает $40 \%$ [5]. Это можно объяснить следующим: излишней осторожностью при проектировании, некачественными изысканиями, неправильным применением методик расчета и, конечно же, недостатками самих используемых методов.

Излишняя осторожность проектировщиков не является оправданной, так как изучение и обобщение опыта строительства зданий на свайных фундаментах из забивных свай показывает, что они, 
как правило, надежнее фундаментов на естественном основании. По статистике, несущественные деформации в несущих конструкциях составляют не более $0,02 \%$ от числа построенных зданий. При этом возникновение деформаций объясняется главным образом неучетом грунтовых условий (заложение нижних концов свай в слабых органогенных и биогенных грунтах и др.), а также ошибками, допущенными в процессе производства работ.

К примеру, одним из интересных обстоятельств является то, что в соответствии с методикой Свода Правил (СП) 24.13330 [6] значения нормативных сопротивлений грунта под нижними концами свай указаны применительно к песчаным грунтам средней плотности, а для плотных песков рекомендуется их увеличивать до 100 \% (табл. 7.2 СП 24.13330). И даже при этом многочисленные сопоставления нормативных значений несущей способности свай при заглублении нижних концов в плотные пески с результатами статических испытаний свай, погруженных в аналогичные грунты, показывают, что несущая способность свай, определенная по СП 24.13330, значительно занижена [7], т. е. даже при двукратном увеличении значении расчетных сопротивлений. Кроме того, практика показывает, что погружение забивных свай в плотные пески возможно не более чем на $0,3-0,5 \mathrm{~m}$.

На рис. 1 приведены кривые зависимости осадок от нагрузок, полученные при испытаниях свай длиной до $7 \mathrm{~m}$, сечением $30 \times 30$ см статической нагрузкой (по материалам института Фундаментпроект). При сравнении этих данных с результатами расчетов по СП 24.13330 можно увидеть существенные различия в значениях расчета несущей способности свай. Таким образом, эти диаграммы непосредственно указывают на целесообразность повышения несущей способности свай, заглубленных в плотные пески.

По данным ряда исследований [7], несущая способность свай, погруженных в плотные пески, оказывается в 1,5-2 раза выше результатов расчетов по СП 24.13330.

Современные нормативно-технические документы в строительстве рекомендуют выполнять расчеты фундаментов, в том числе свайных, с учетом физической и геометрической нелинейности, с помощью численных методов, реализованных в популярных программных комплексах, таких как PLAXIS [8], Rocscience RS [9], ABAQUS [10], SCAD [11]. В СП 24.13330.2011 существует требование о необходимости выполнения расчетов свайных фундаментов с построением математических моделей, описывающих их механическое поведение для расчетов по первому или второму предельному состоянию. Также рекомендуется выполнять верификацию выбранных моделей, отражающих механизмы взаимодействия свайных фундаментов и прилегающих грунтовых массивов для выполнения геотехнических расчетов. Однако при этом не приводятся рекомендации по выбору подобных моделей, более того не представлен состав моделей, которые возможно применять в тех или других грунтовых условиях (кроме эмпирического решения по п. 7.2.2 СП 24.13330.2011).

В статье представлен краткий обзор существующих аналитических методик расчетов несущей способности забивных висячих свай, используемых в отечественной и международной практике геотехнических расчетов. Показана сложность взаимодействия сваи с грунтом, и раскрыты основные факторы, влияющие на этот процесс. Сделан краткий сопоставительный анализ результатов аналитических расчетов и сравнение их с результатами, полученными в процессе полевых (практических) испытаний свай.

\section{Механизм работы сваи в грунтовом массиве}

Момент достижения предельного состояния грунта в основании сваи, как правило, определяет максимальную несущую способность сваи. Это относится к сваям любых типов. Однако такому состоянию соответствуют высокие значения осадки сваи, поэтому в практике проектирования расчет несущей способности сваи выполняет оценочную роль и служит для дальнейших определений максимально допустимой нагрузки на сваю и предварительному определению конструкции фундамента. В общем виде, работа висячей сваи, располо-

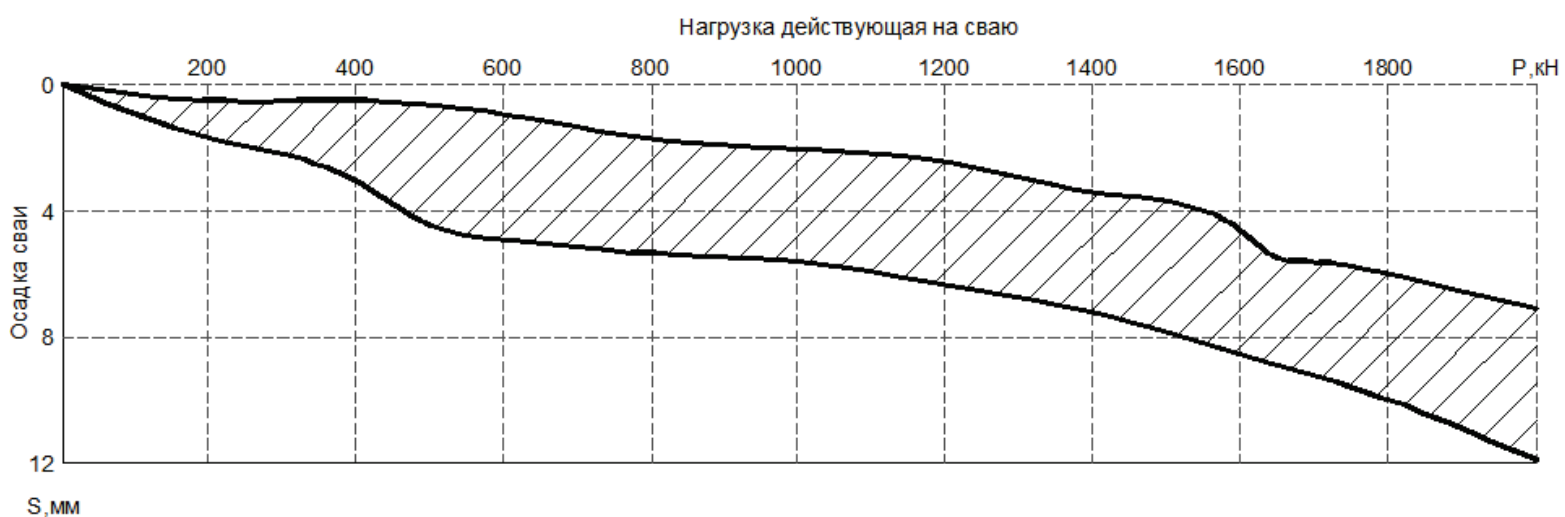

Pис. 1. Зависилость осадок свай, погруженных в плотные пески, от нагрузок

Fig. 1. Piles loading $(P, k N)$ versus settlements $(S, m m)$ into dense sands 
женной в дисперсных грунтах, определяется двумя компонентами (1): сопротивлением ствола $\left(R_{s}\right)$ сваи, за счет бокового трения, и сопротивлением основания сваи $\left(R_{b}\right)$ при опирании на грунт:

$$
R=R_{s}+R_{b}=\int_{0}^{L} f_{s}(z) p(z) d z+A_{b} q_{b},
$$

где $f_{s}$ - сопротивление сваи по боковой поверхности; $A_{b}$ - площадь основания сваи; $q_{b}$ - удельное сопротивление под острием сваи.

Правда, при строгой научной постановке, такой подход не может считаться в достаточной степени обоснованным. $\mathrm{K}$ примеру, при погружении сваи формируется уплотненное грунтовое ядро в области ее нижней части, которое участвует в работе совместно, а не раздельно, с «Пятой» и «стволом» сваи. Другими словами, механизм взаимодействия сваи и окружающего грунта является комплексным и сложным процессом, который зависит от многих факторов:

- сложности инженерно-геологических условий;

- истории образования грунтовых массивов (которая, в частности, определяет степень недоуплотненности или переуплотненности слагающих их грунтов), их текущего и прогнозного состояния (в том числе напряженно-деформированного);

- строения и состава окружающих грунтов, их физических и механических свойств;

- глубины погружения сваи;

- технологии погружения;

- типа свай, их физических и геометрических параметров;

- функционального режима нагружения и интенсивности нагрузок;

- геотехнической сложности (плотность окружающей застройки, сложности проекта и пр.).

- процессов, изменяющихся во времени, и др.

Не малую роль в механизме взаимодействия свай с грунтом играет сложность и характер нагружения конструкции свай. На первом этапе нагружения, при невысокой вертикальной нагрузке конструкции сваи, ее взаимодействие с окружающим грунтом происходит по упругой (при этом нелинейной) зависимости, без нарушения структурных связей в прилегающем грунте. При разгрузке конструкции сваи осадки восстанавливаются. Здесь характер работы сваи отражает классический механизм «сваи-трения», т. е. внешняя нагрузка воспринимается за счет бокового трения и не передается на основание сваи.

При дальнейшем нагружении, на втором этапе, начинают накапливаться необратимые сдвиговые деформации, что отражается нелинейным и пластическим характером деформирования. При этом в некоторых слоях грунта касательные напряжения и деформации достигают предельных значений, т. е. свая на отдельных участках достигает предельных значений сдвиговой осадки $S_{0}$. Сопротивление трению по боковой поверхности сваи снижается до минимальных значений, и происходит перераспределение усилий от ствола сваи к ее основанию. При достижении осадки, равной предельной сдвиговой, наступает «срыв» сваи, и дальнейшая осадка сваи носит незатухающий характер, без увеличения нагрузки (рис. 2).

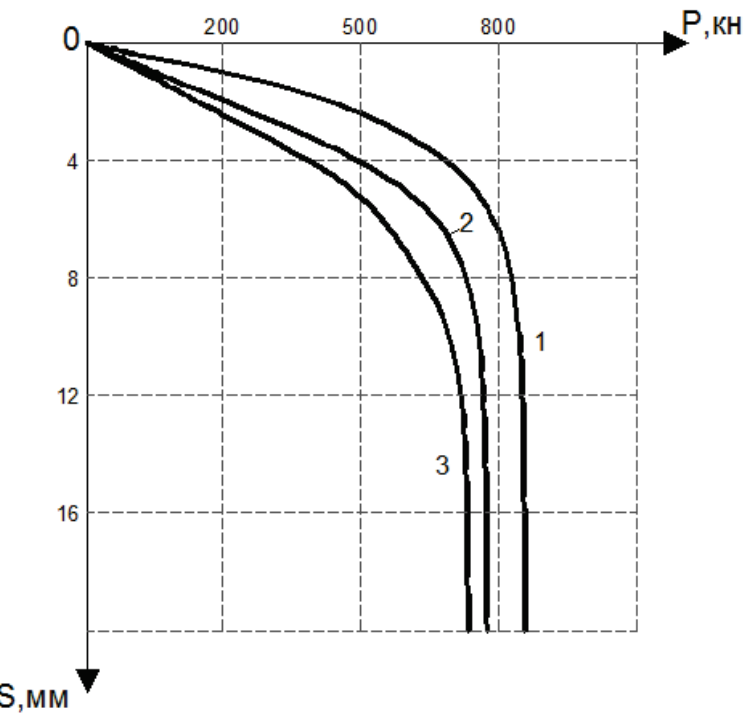

Pис. 2. График зависилости осадки S от нагрузки Р для свай, погруженных в глинистых грунтах: 1 - твердой и полутвердой консистенции; 2 - полутвердой консистениии; 3- тугопластичной консистенции

Fig. 2. Piles loading $(P, k N)$ versus settlement rate $(S, \mathrm{~mm})$ into clays: 1 - very stiff clay; 2 - stiff clay; 3 -low plasticity clay

Таблица 1. Предельные сдвиговые осадки свай

Table 1. Limits of pile axial displacements for various soil types

\begin{tabular}{|c|c|}
\hline $\begin{array}{l}\text { Наименование грунта } \\
\text { Soil description }\end{array}$ & \begin{tabular}{|c|} 
Предельная \\
сдвиговая \\
осадка, $S_{0}$, мм \\
Axial displace- \\
ments limit, mm
\end{tabular} \\
\hline $\begin{array}{l}\text { Песок мелкозернистый, средней плотности } \\
\text { Fine-grained sand, medium density }\end{array}$ & 5 \\
\hline $\begin{array}{l}\text { Супесь легкая, пылеватая, средней плотности } \\
\text { Light sandy loam, dusty, medium density }\end{array}$ & 6 \\
\hline $\begin{array}{l}\text { Супесь легкая, пылеватая } \\
\text { с растительными остатками, мягкопластичная } \\
\text { Light sandy loam, silty with plant residues, soft-plastic }\end{array}$ & 7 \\
\hline $\begin{array}{l}\text { Суглинок тугопластичный } \\
\text { Loam hard plastic }\end{array}$ & 9 \\
\hline $\begin{array}{l}\text { Суглинок пылеватый, с гравием, } \\
\text { мягкопластичный (морена) } \\
\text { Loamy loam, with gravel, soft-plastic }\end{array}$ & 10 \\
\hline $\begin{array}{l}\text { Суглинок пылеватый, слоистый, мягкопластичный } \\
\text { Loamy, layered, soft-plastic }\end{array}$ & 15 \\
\hline $\begin{array}{l}\text { Суглинок пылеватый, ленточный, мягкопластичный } \\
\text { Loamy, belt, soft-plastic }\end{array}$ & 18 \\
\hline $\begin{array}{l}\text { Глина пылеватая, ленточная, тугопластичная } \\
\text { Clay dust, belt, hard plastic }\end{array}$ & 22 \\
\hline $\begin{array}{l}\text { Глина пылеватая, ленточная, мягкопластичная } \\
\text { Clay dust, belt, soft-plastic }\end{array}$ & 25 \\
\hline
\end{tabular}

Значения предельных сдвиговых осадок зависят от типа грунтов, их строения, состава и состоя- 
ния. В 60-х гг. прошлого столетия, на основе статических испытаний, проведенных «Ленинградоргстроем» [12], были получены значения предельных сдвиговых осадок свай для некоторых типов грунтов (табл. 1). Предельная сдвиговая осадка это осадка, при которой прекращается дальнейшее искривление слоев грунта около сваи (депланация) и происходит срез грунта около ствола. Различные значения предельных сдвиговых осадок косвенно указывают на различные механизмы взаимодействия свай с грунтом не только в разных местах устройства сваи, а также на разных отрезках ствола в пределах одной сваи по глубине.

На третьем этапе, при достижении нагрузок, близких к предельным, работа сваи происходит преимущественно за счет сопротивления грунта в зоне опирания нижнего конца сваи, т. е. характер работы сваи в грунте напоминает работу «сваистойки» (рис. 3).

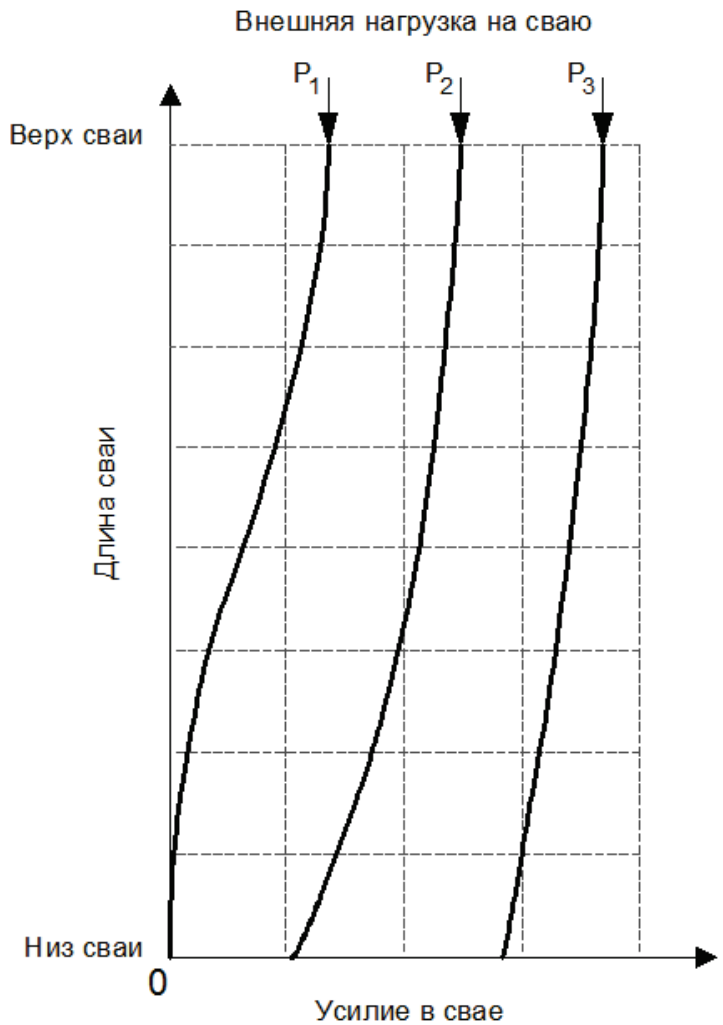

Рис.3. Распределение усилий в свае по длине в зависимости от уровня загрузки

Fig. 3. Loads intensities and its distribution in piles

\section{Особенности взаимодействия сваи с глинистыми грунтами}

При погружении свай в тонкодисперсные грунты происходит радиальное и вертикальное смещение частиц грунта и поровой несвязной воды. Это приводит к нарушению структуры грунта, к его уплотнению и росту порового давления вокруг сваи. В глинистых грунтах пластичных консистенций восстановление порового давления может занять несколько месяцев, что отражается в медлен- ном наборе несущей способности этих грунтов. В строительной практике это явление называют эффектом «засасывания» сваи. В период восстановления снижается поровое давление, происходит воссоздание структурных связей, грунты мягкопластичной и текучепластичной консистенции восстанавливают прочность и как бы обжимают сваю, происходит рост эффективного вертикального давления и пассивного горизонтального давления (нормального давления). В этот период можно наблюдать снижение эффекта набухания грунта на поверхности земли вокруг сваи.

Тиксотропные эффекты в грунтах, окружающих сваю, необходимо учитывать при проектировании свайных фундаментов, так как прочностные характеристики грунта, полученные на этапе геологических изысканий и лабораторных исследований, могут быть восстановлены только спустя значительный промежуток времени после устройства свайного фундамента. Например, для скандинавских глин процесс восстановления несущей способности свай занимает порядка одного года.

Наряду с собственно тиксотропией грунты могут проявлять квазитиксотропные свойства [13], т. е. частичное восстановление прочности после нагрузок.

Юрские глины Московского региона при нарушении их состояния существенно и, как правило, необратимо теряют свои первоначальные прочностные характеристики. Эти грунты, располагающиеся на значительных глубинах, в силу генетического формирования имеют высокую пористость (коэффициент пористости (e), как правило, больше единицы) и находятся в слабоуплотненном $\left(\rho=1,7-1,8\right.$ т $\left./ \mathrm{M}^{3}\right)$, но твердом состоянии $\left(I_{l} \approx 0\right)$, что предопределяет высокую изменчивость их свойств в случае нарушения их состояния. Так, при разгрузке этих грунтов, вызванных снятием вышележащих отложений, происходит их разуплотнение, что приводит к образованию трещин. И в случае попадания грунтовых вод при устройстве фундаментов или в процессе эксплуатации зданий (при попадании атмосферных вод через поверхность соприкосновения сваи с грунтом) это ведет к их набуханию, снижению показателя их консистенции и, как следствие, к ухудшению прочностных и деформационных характеристик в 2-5 раз [14].

Погружение свай в глины твердой консистенции также сопровождается смещением частиц грунта, уплотнением и снижением влажности грунтов, но при этом возможно развитие процесса трещинообразования. Закономерность развития трещин, как правило, определяется структурнотекстурными особенностями грунтов. Так, в ленточных глинах наблюдается глубокое развитие трещин вдоль плоскости слоев. В отличие от пластичных глин, в твердых глинах деформации смещения могут иметь необратимый характер, т. е. на протяжении всего жизненного цикла строительства и эксплуатации здания прочность грунтов не будет восстановлена. Различными экспери- 
ментальными наблюдениями [15] установлено, что зона уплотнения грунта вокруг сваи на поверхности земли достигает 8 диаметров, а на уровне основания сваи - до 4,5 диаметров сваи.

В процессе погружения сваи имеет место явление в строительной практике называемое «ложным отказом». При этом может наблюдаться кратковременное увеличение прочности грунта под подошвой сваи. В дальнейшем в процессе релаксации напряжений в грунтах их прочность в основании сваи будет снижаться, т. е. будет достигнут действительный отказ сваи. Здесь нельзя забывать, что на изменчивость свойств глинистых грунтов во времени, при прочих равных, весьма значительно влияют условия образования данных отложений. Очевидно, что реология флювиогляциальных, аллювиальных или морских образований может отличаться в весьма широких пределах. К сожалению, в отличие от грунтоведения, генетический подход в механике грунтов получил гораздо меньшее развитие.

В городах, расположенных в устьях рек, часто приходится возводить здания и сооружения на значительной толще слабых грунтов, превышающей 20-30 м. Эта толща состоит в том числе из слоев органогенных, биогенных и глинистых грунтов в текучем состоянии. Такие условия предопределяют использование свайных фундаментов зданий и сооружений. Однако во многих случаях даже при длине свай 20 м они получаются висячими и имеют несущую способность по грунту существенно ниже, чем может выдержать железобетонная свая по материалу. Кроме всего прочего, в районах речных долин со сложным и специфическим формированием пойменного или руслового аллювия характеристики сопротивления свай могут существенно отличаться от значений, указанных в нормативно-технической документации. Так, по региональным нормам для Санкт-Петербурга нор- мативные сопротивления трению глинистых грунтов по боковой поверхности свай превышают в 1,5-2 раза аналогичные значения, приведенные в федеральных нормах (для глин с $\left.I_{l}=0,3-0,7\right)$ [16].

Очевидно, что геометрические и жесткостные параметры свай отражаются на значениях несущей способности. Увеличение размера сечения забивной сваи влияет на объем уплотняемого грунта, что отражается в увеличении радиальных (нормальных) напряжений на ствол сваи, а значит и на уровень сопротивления сваи трению (2):

$$
f_{s}(z)=\sigma_{v}^{\prime}(z) \operatorname{Ktg}(\delta),
$$

где $\sigma_{v}^{\prime}-$ природное давление грунта на глубине $z$; $K$ - боковое давление грунта; $\delta$ - угол трения боковой поверхности сваи о грунт (допустимо принимать равным $\delta=\varphi-5$, где $\varphi-$ угол внутреннего трения).

При этом различными экспериментами установлена обратная зависимость удельной несущей способности $q$ от поперечного размера сваи. Так, по данным опытов [17], разница между величинами предельного давления наименьшая для свай в рыхлых песках и наибольшая в плотных песках (рис. 4).

Влияние размеров поперечного сечения сваи на изменение предельного давления при прочих равных условиях называют масштабным эффектом. C уменьшением угла внутреннего трения грунтов влияние масштабного эффекта уменьшается, а в глинистых недренируемых грунтах это явление почти не наблюдается.

Как уже было упомянуто выше, многие связные грунты обладают тиксотропией, или способностью частично или полностью восстанавливать прочность через некоторое время после нарушения структурных связей (разупрочнения) вследствие действия внешней нагрузки. Разупрочнение грунта наступает вследствие нарушения структурных связей между его частицами и может проявляться

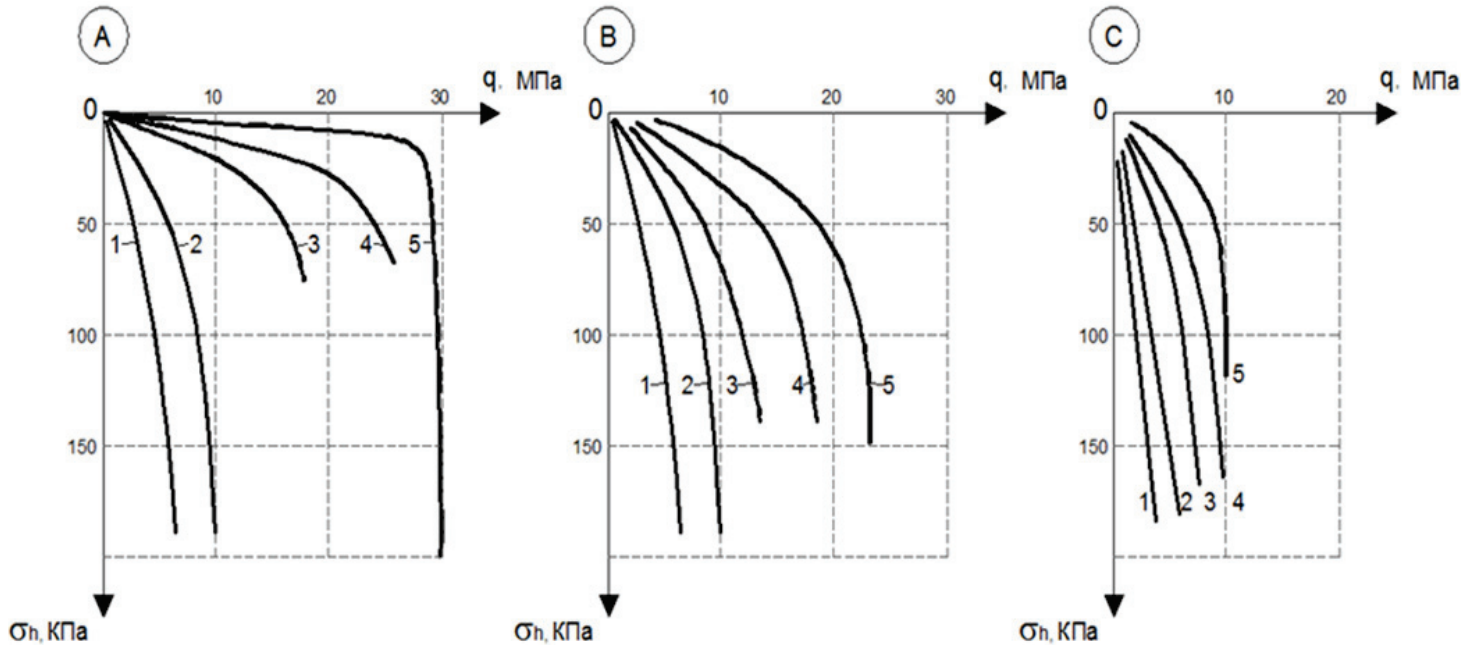

Pис. 4. Изленение удельного давления q на сваи в зависилости от их диаметра и бокового давления грунта. $A$ - песок плотный; В - пе-

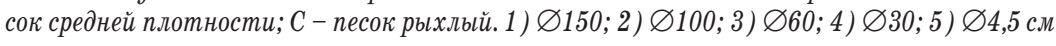

Fig. 4. Specific pressure distribution on piles versus piles diameter, soil types and horizontal earth pressure. A-dense sand; $B-$ medium dense sand; $C$ - loose sand. 1) Ø150;2) Ø100; 3) Ø60;4) Ø30; 5) Ø4,5 cm 
как в виде разжижения (полной потери прочности), так и в виде некоторого размягчения (частичного снижения прочности).

Наблюдениями установлено, что размягчение и разжижение связных грунтов наиболее интенсивно происходит в зоне нарушения структурных связей при наличии свободной воды. Если ее нет, то в процессе разрушения структурных связей грунта связанная вода трансформируется в свободную. Чем больше свободной воды в зоне деформации грунта, тем легче нарушаются структурные связи в процессе погружения свай, способствуя облегчению их заглубления. В свою очередь, чем больше нарушено связей, тем ниже сопротивление сдвигу грунтов, а следовательно, их несущая способность. Поэтому наиболее низкой несущей способностью обладают сваи, погруженные в текучие, а также текучепластичные связные грунты.

После погружения свай в слабые глинистые грунты происходят сложные процессы по восстановлению нарушенной структуры грунта (в первую очередь, тиксотропному упрочнению) вокруг каждой сваи, в результате чего увеличиваются силы трения грунта о боковую поверхность свай и, как следствие этого, возрастает их несущая способность - эффект «засасывания» (рис. 5). В результате ряда исследований и полевых испытаний свайных фундаментов было установлено, что в зависимости от свойств грунтов значительное увеличение несущей способности наблюдается в первые 6-80 суток с момента прекращения погружения свай.

Как уже было сказано, функциональный режим и интенсивность нагружения сваи также влияет на ее показатели несущей способности. Так, влияние времени на несущую способность за счет работы ствола свай в слабых глинистых грунтах изучал J.B. Burland [18]. Он проводил полевые испытания в городе Мехико, когда разделил механизм формирования касательных напряжений за счет эффективного трения свай и эффективного сцепления. Ожидаемо был отмечен медленный рост предельного сопротивления ствола сваи во времени в процессе набора деформаций (мобилизация прочности за счет полного включения в работу). Однако было установлено, что при замедлении процесса нагружения свай (с 10 до 0,001 мм/мин) отмечается существенное снижение сопротивления свай. Так, коэффициент сцепления (адгезии) свай с грунтом был снижен на 50 \% , т. е. при медленном и длительном нагружении сваи зацепление частиц грунта о поверхность сваи не происходит, т. к. свая находится в постоянном, хоть и в медленном, процессе погружения - т. е. в данном случае несущая способность сваи о боковую поверхность будет определяться только силами трения грунта. Здесь важно отметить, что скорость нагружения не влияет на несущую способность свай, расположенных в твердых глинистых грунтах, но при этом возможно снижение их прочности за счет реологических процессов, свойственных таким грунтам. К примеру, применительно к Лондонским твердым глинам, снижение несущей способности свай составляло до $20 \%$ за 9-ти месячный период наблюдений [19].

Практикой установлено, что начальное сопротивление одинаковых по размерам свай сразу после окончания их погружения в одни и те же слабые глинистые грунты одним и тем же способом может существенно различаться [20]. Однако спустя несколько часов разброс значений несущей способности уменьшается. В грунтах текучей и текучепластичной консистенции отсутствует существенное уплотнение грунтов вблизи забиваемых свай, поэтому удельные силы трения и связанное с ними упрочнение свай почти не зависят от разме-

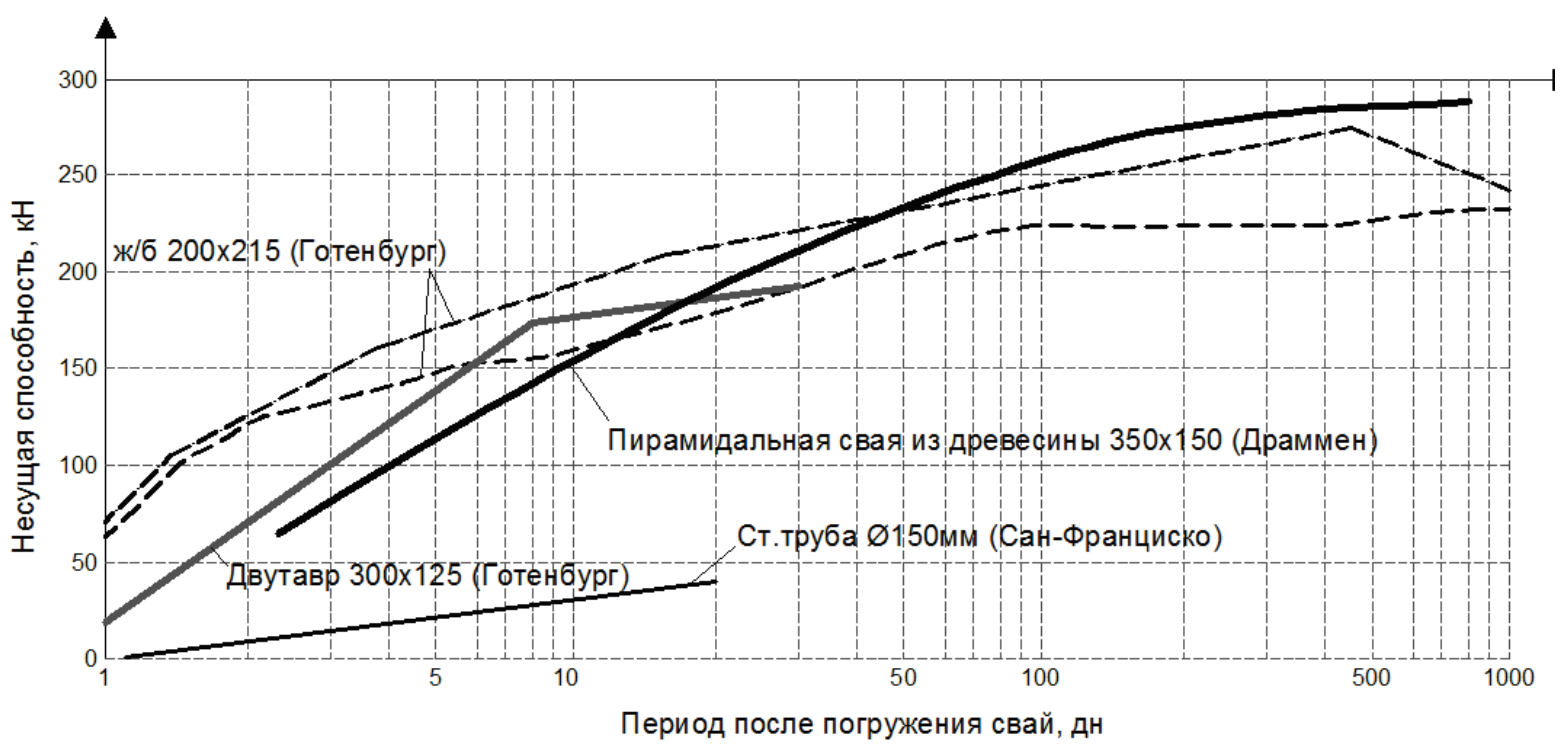

Puc. 5. Зависимость набора прочности свай во врелени в слабых глинистых грунтах

Fig. 5. Gain in bearing capacity with increasing time after driving of piles into soft clays 
ров их поперечного сечения (в диапазоне от 0,3 до 0,8 м). Вследствие этого размер сечения свай в этих грунтах не оказывает заметного влияния на изменение прироста их несущей способности. Таким образом, можно считать, что решающее влияние на удельную несущую способность свай в период эксплуатации сооружения оказывают физико-механические свойства глинистых грунтов с показателем текучести $I_{l}>0,5$, и мало влияют способ заглубления, размеры поперечного сечения, материал свай и характер их нагружения.

Интересные наблюдения были сделаны Научно-исследовательской ассоциацией инженеров строителей [21] в Великобритании в 1969 г. при проведении серий экспериментальных исследований взаимодействия свайных фундаментов с грунтами. В качестве забивных свай были использованы стальные трубы $\varnothing 168$ мм, длиной 5,6 м, погруженные в глинистые грунты твердых консистенций. Серию испытаний проводили в течении года после забивки. Результаты исследований показали, что при погружении свай вдавливанием и забивкой в устье скважины - в области верхней части сваи, формировался технологический зазор глубиной до 8 диаметров сваи. При этом в процессе наблюдения за грунтом в области технологического зазора в течении одного года было установлено, что зазор не был закрыт в процессе реологического восстановления грунта. По данным измерений сила сцепления (адгезии) грунта со сваей была незначительной на глубине от 8 до 14 диаметров сваи, а при больших глубинах (>16 d) была зафиксирована максимальная адгезия грунта, превышавшая сдвиговую прочность недренированного грунта до $20 \%$, которая сформировала плотный слой ( «корку») грунта толщиной 1-5 мм, работающий совместно со сваей при ее осадках, т. е. линия предельного сопротивления проходила не по границе сваи, а была расположена внутри грунтового массива на некотором расстоянии от сваи. Очевидно, что сила сцепления (адгезия) грунта зависит от сдвиговой прочности недренированного связного грунта и его физических параметров (плотность, показатель текучести). При этом при снижении показателя текучести адгезия грунта также снижается [19].

Результаты измерений показали, что, несмотря на повреждение структуры глинистого грунта, непосредственно примыкающего к свае, процессы консолидации грунта не повлияли на величину сопротивления грунта по боковой поверхности сваи. Хотя при этом было зафиксировано отрицательное поровое давление грунта в зоне непосредственного примыкания к свае, которое, однако, восстанавливалось в течении 48 часов.

Индикаторы деформирования, которые были установлены на сваях, зафиксировали следующий характер распределения усилия по глубине (рис. 6).

Таким образом, по результатам анализа экспериментов было установлено, что сопротивление грунта о боковую поверхность при прочих равных также зависит от: уровня переуплотнения грунта (Over Consolidation Ratio - OCR) и жесткости (гибкости) ствола сваи.

Уровень переуплотнения грунта (OCR) в данном случае выступает как количественная характеристика, отражающая литогенетические усло-

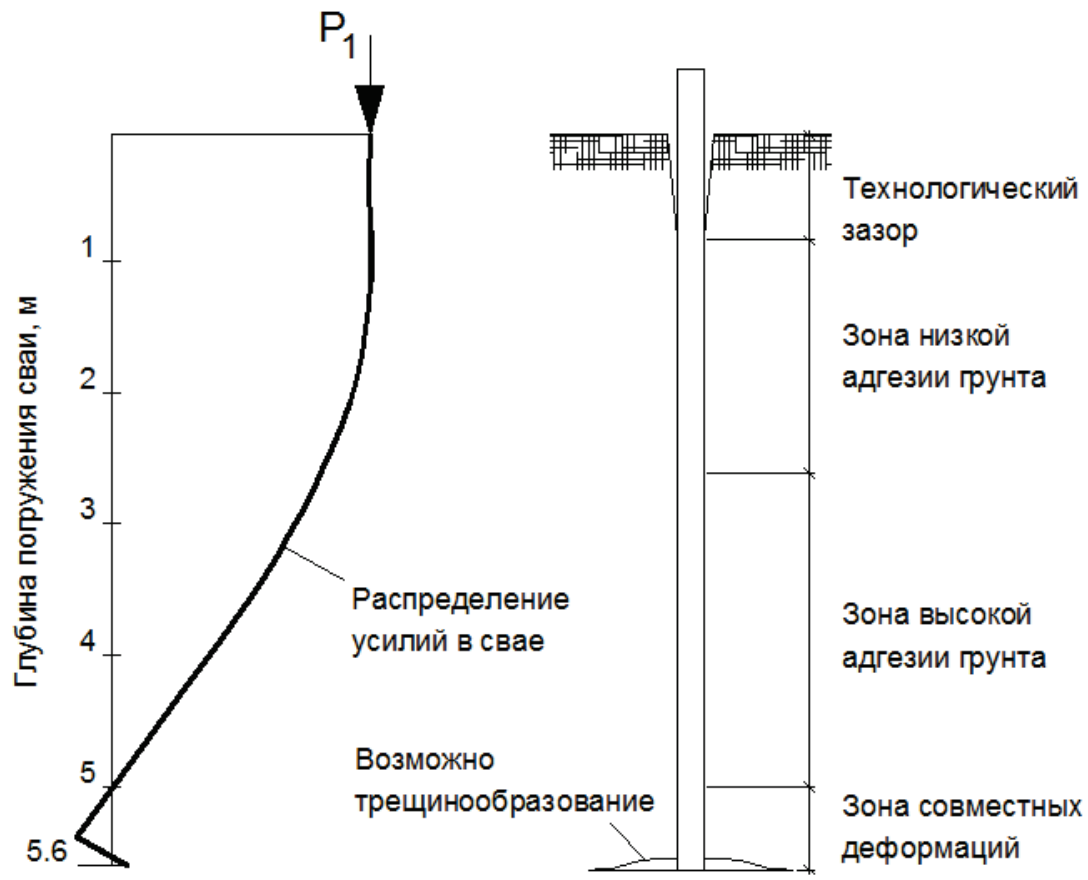

Puс.6. График распределения усилий в свае

Fig. 6. Load transfer from pile to stiff clay 


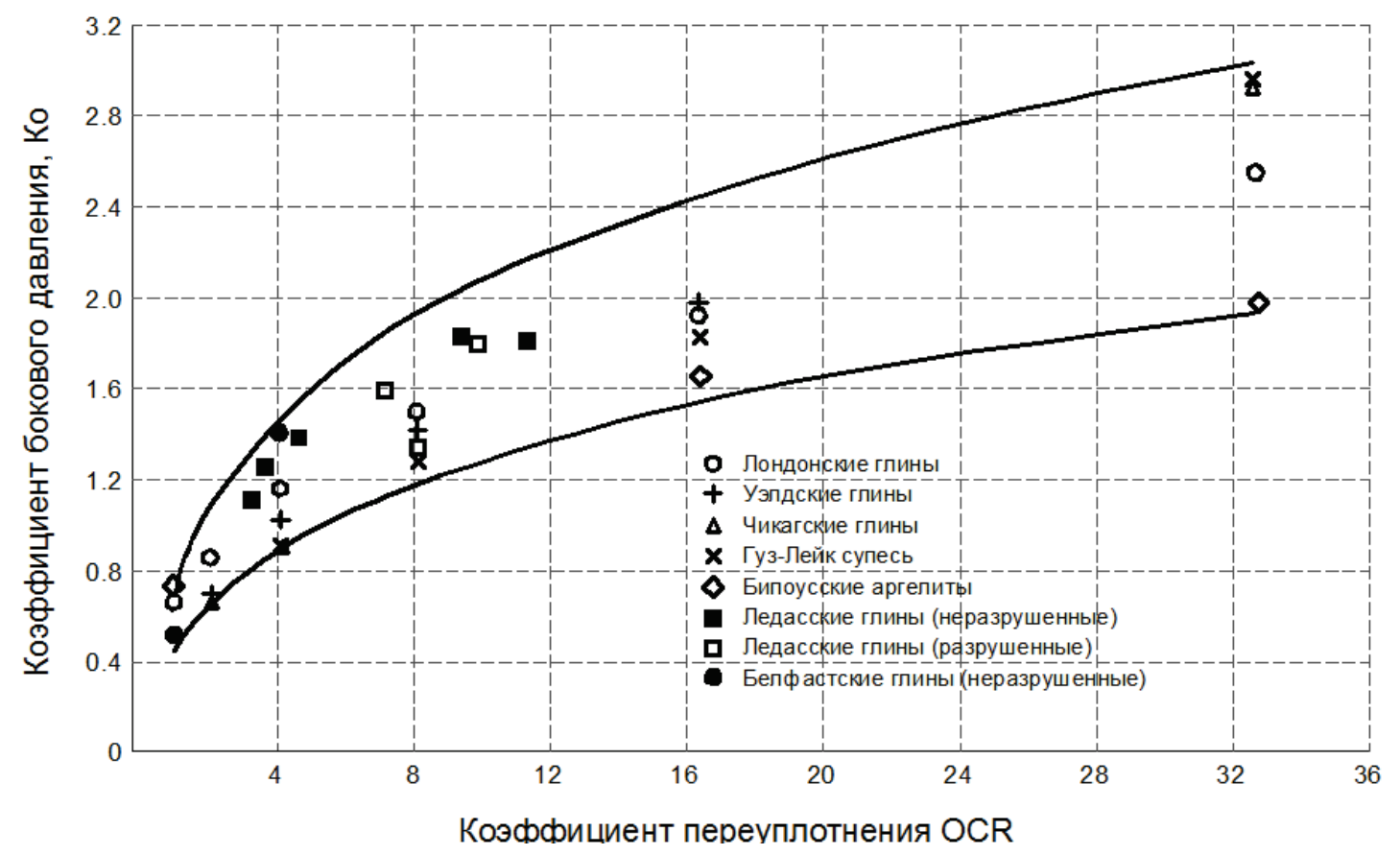

Pис. 7. Зависимость коэффициента бокового давления $K_{0}$ от исторического давления в грунте

Fig. 7. Values of $K_{0}$ and OCR for various materials

вия образования и возраст дисперсных грунтов. Под степенью переуплотнения пород (OCR) понимается отношение максимального давления, которое испытал грунт при предыдущем нагружении, к давлению, испытываемому в данный момент времени. Данная характеристика непосредственно влияет на эффективное горизонтальное напряжение в массиве грунта, а значит и на уровень горизонтальных напряжений, действующих на ствол сваи, выраженных через коэффициент бокового давления покоя $K_{0}$ (рис. 7) [19, 22]. Под коэффициентом бокового давления грунта $K_{0}$ понимается отношение горизонтального эффективного напряжения $\sigma_{h}^{\prime} \kappa$ вертикальному $\sigma_{v}^{\prime}$ при отсутствии горизонтальных деформаций $\left(\varepsilon_{h}=0\right)$.

При этом ранее на основе многочисленных наблюдений была построена кривая зависимости коэффициента переуплотнения массива грунта и коэффициента адгезии грунта $\alpha$. Для удобства практических расчетов здесь OCR представлен как отношение сдвиговой прочности недренированного грунта $\tau_{u}$ и эффективного вертикального давления $\sigma_{v 0}$ (рис. 8).

Похожая закономерность распределения касательных напряжений и картина деформирования (депланации) слоев грунта была зафиксирована при полевых экспериментальных испытаниях свай, проводившихся сотрудниками НИИОСП в нашей стране, в г. Херсоне и Душанбе [23], хотя авторами этих экспериментов не была зафиксирована закономерность появления технологического зазора.

Совершенно очевидно, что факт возникновения технологического зазора необходимо учитывать при расчете и проектировании свайных фундаментов. Учитывая, что появление такого зазора при технологическом погружении сваи зависит, в том числе, от длины сваи и ее диаметра, М. Томлинсон $[19,21]$ предложил в расчетах вводить коэффициент гибкости $F$ (рис. 9). В целом очевидно, что образование технологического зазора влияет на несущую способность сваи по боковой поверхности, а также создает опасность реструктуризации грунтов, ухудшения их физических и механических свойств посредством попадания атмосферных или подземных вод в низлежащие слои грунта, состоящие из плотных глин твердых консистенций.

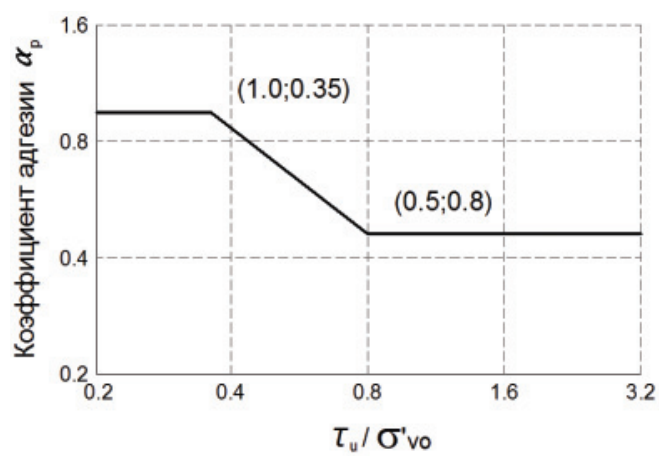

Puс.8. Зависимость коэффициента адгезии от уровня переуплотнения грунта

Fig. 8. Adhesion factor versus loading history

Кроме вышеуказанной специфики взаимодействия свай с глинистыми грунтами всегда должны учитываться региональные особенности инженерно-геологических условий. Так, в работе [15] ука- 
зывается, что в элювиальных глинистых грунтах Среднего Урала несущая способность по боковой поверхности составляет $60-70 \%$, а по острию 40-30\%, в то время как в глинистых грунтах осадочного происхождения сваи работают практически как сваи-стойки, сопротивление по острию для грунтов с одинаковыми показателями консистенции в элювиальных грунтах в 5-7 раз меньше, а по боковой поверхности на - 30-50\% выше сопротивлений, рекомендуемых в нормативно-технической документации.

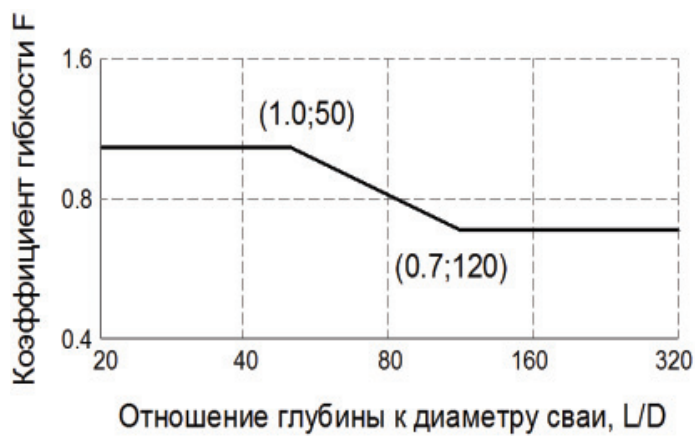

Рис.9. Зависимость коэффициента гибкости от жесткости и глубины погружения

Fig. 9. Length factor versus overall embedded length

Особенности взаимодействия сваи с песчаными грунтами

В отличии от эмпирического подхода при определении несущей способности одиночной сваи, который используется в нашей стране, в международной практике [24-26] распространена формула (3) для расчета несущей способности в песчаных грунтах, базирующаяся на модели прочности Кулона-Мора:

$$
Q_{p}=N_{q} \sigma_{v o}^{\prime} A_{b}+\frac{1}{2} K_{s} \sigma_{v o}^{\prime} \operatorname{tg} \delta A_{s},
$$

где $\sigma_{v o}^{\prime}$ - эффективное вертикальное давление грунта на уровне основания сваи; $N_{q}$ - эмпирический коэффициент несущей способности грунта, который зависит от отношения глубины погружения сваи и ее диаметра, а также от угла трения грунта (рис. 10); $A_{b}$ - площадь основания сваи; $A_{s}-$ площадь ствола сваи; $K_{s}$ - эмпирический коэффициент горизонтального давления, зависящий от плотности и состояния грунта, а также физических и геометрических параметров сваи; $\delta$ - угол трения между сваей и грунтом.

Из приведенной формулы (3) очевидно, что значения сопротивления сваи по боковой поверхности и на уровне основания в несвязных грунтах зависят от диаметра сваи и ее длины. При погружении забивной сваи в грунт происходит уплотнение и частичное выдавливание окружающего грунта, меняется его структура, увеличивается плотность, т. е. чем больше размер сваи, тем выше сопротивление грунта (рис. 10).

Также имеет место временная зависимость несущей способности сваи в песчаных грунтах, когда в процессе релаксации грунта несущая способность снижается.

Явление уплотнения песков при погружении забивных свай относится к пескам в рыхлом или среднеплотном сложении. При погружении нижнего конца свай в плотные пески может наблюдаться обратное явление - разуплотнение грунта.

Эмпирический коэффициент горизонтального давления $K_{s}$ является параметром, который учитывает такие факторы, влияющие на горизонтальное давление, как: история напряженно-деформированного состояния массива, геометрические размеры сваи (диаметр, длина), жесткость и материал сваи.

История напряженного состояния массива оценивается коэффициентом давления покоя $K_{0}$ в ненарушенном состоянии. Данный показатель мо-

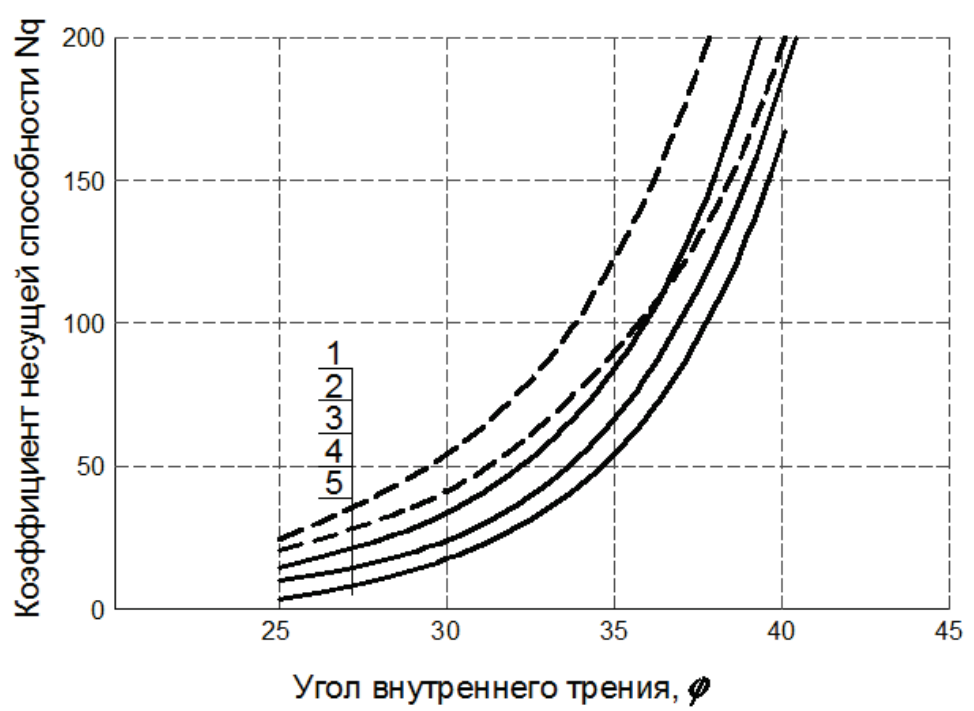

1- $D / B=20$ (Brinch Hansen);

2- $D / B=5$ (Brinch Hansen);

3- $D / B=5$ (Березанцев);

4- $D / B=20$ (Березанцев);

5- D/B=70 (Березанцев);

Рис. 10. Диаграммы зависимости коэффиииента несущей способности от соотношения длины сваи кее диаметру (по В.Г. Березанцеву u Brinch Hansen)

Fig. 10. Bearing capacity factors by V.G. Berezantsev and Brinch Hansen 
жет быть определен, к примеру, прессиометрическими испытаниями грунта. В нормально уплотненных грунтах $(\mathrm{OCR}=1) K_{0}$ не изменяется по глубине, а зависит от плотности грунта. Средние значения для $K_{0}$ для песчаных грунтов могут быть следующими: для рыхлых грунтов $K_{0}=0,5$, для песков средней плотности $K_{0}=0,45$, для плотных $K_{0}=0,35$. Для переуплотненных грунтов $K_{0}$ может иметь существенно большие значения - от 1 до 2 и более.

В нормально уплотненных грунтах сопротивление погружению сваи на поверхности относительно невелико, но увеличивается (как правило линейно) с глубиной погружения. В переуплотненных массивах сопротивление на поверхности значительно выше, при этом возможно снижение сопротивления с глубиной.

В.Г. Березанцевым и F.H. Kulhawy [24] были рассчитаны значения сопротивлений оснований забивных свай ( $\varnothing 1220$ мм) на уровне нижнего конца свай, для песков плотных и рыхлых, и построен график, отражающий изменение сопротивления сваи в грунте на уровне ее основания (рис. 11). В международной практике проектирования данные этих экспериментальных исследований иногда используются для предварительных расчетов свайных фундаментов, расположенных в песках.

На основе подобных исследований в нашей стране была разработана схожая методика, которая сейчас активно применяется в отечественной практике проектирования и регламентируется в СП 24.13330.

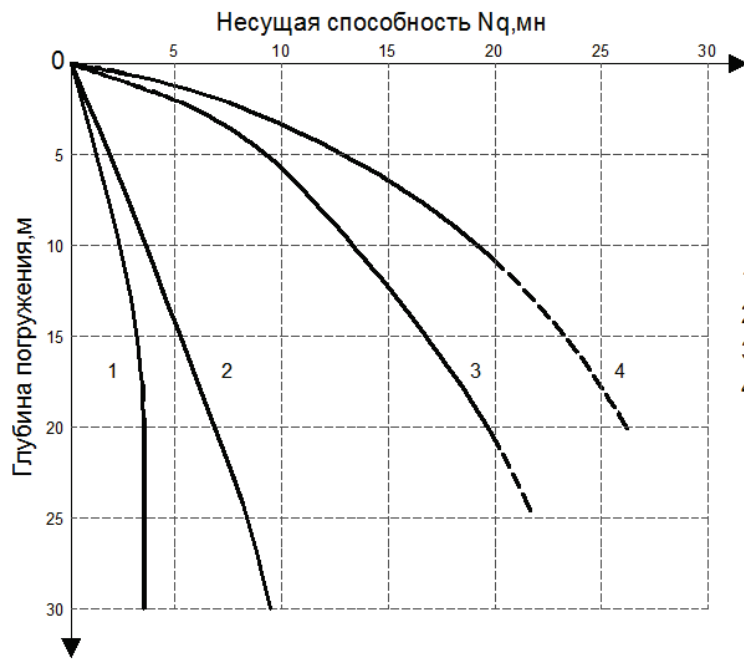

1- Nq для рыхлых песков (по Березанцеву);

2 - Nq для рыхлых песков (по Kulhawy);

3 - Nq для плотных песков (по Kulhawy);

4 - Nq для плотных песков (по Березанцеву);

Pис. 11. График зависимости несущей способности $\mathrm{Nq}$ основания сваи (Ø1220 мл) от глубины погружения

Fig. 11. Base resistance versus penetration depth into sand

\section{Методы исследований несущей способности сваи}

Методика расчета несущей способности свайного фундалента по СП 24.13330. Данная методика является широко известной среди проектировщиков и неплохо зарекомендовавшей себя в нашей стране. Она является сугубо эмпирической, была предложена еще в 50-х гг. прошлого века А.А. Лугой и основывается на данных многочисленных наблюдений за работой свайных фундаментов. Несколько позже данная методика дорабатывалась в НИИОСП им. Н.М. Герсеванова в отношении показателей расчетного сопротивления по боковой поверхности $f_{i}$ для слабых глинистых грунтов с показателями текучести $I_{l}=0,7 . .0$.

В соответствии с данной методикой, несущую способность $F_{d}$, кН висячей забивной и вдавливаемой свай и сваи-оболочки, погружаемой без выемки грунта, работающих на сжимающую нагрузку, следует определять как сумму расчетных сопротивлений грунтов основания под нижним концом сваи и на ее боковой поверхности по формуле (4):

$$
F_{d}=\gamma_{c}\left(\gamma_{c R} R A+u \sum \gamma_{c f} f_{i} h_{i}\right)
$$

где $\gamma_{c}-$ коэффициент условий работы сваи в грунте, обычно принимаемый равным единице; $R$ - расчетное сопротивление грунта под нижним концом сваи, кПа; $A$ - площадь опирания на грунт сваи, $\mathrm{M}^{2}$, принимаемая по площади поперечного сечения сваи брутто или по площади поперечного сечения камуфлетного уширения по его наибольшему диаметру, или по площади сваи-оболочки нетто; $u$ наружный периметр поперечного сечения ствола сваи, м; $f_{i}$ - расчетное сопротивление $i$-го слоя грунта основания на боковой поверхности сваи, кПа, принимаемое по табл. 7.3 СП 24.13330; $h_{i}-$ толщина $i$-го слоя грунта, соприкасающегося с боковой поверхностью сваи, м; $\gamma_{c R}, \gamma_{c f}-$ коэффициенты условий работы грунта соответственно под нижним концом и на боковой поверхности сваи, учитывающие влияние способа погружения сваи на расчетные сопротивления грунта.

В рассматриваемой методике ключевыми параметрами являются расчетные сопротивления $R$ и $f_{i}$, которые определяются по табл. 7.2, 7.3 СП 24.13330.

Для анализа этой методики расчета нами были построены диаграммы зависимости основных параметров расчетных сопротивлений $R$ и $f_{i}$ для пылевато-глинистых грунтов (рис. 12,13$)$.

При сравнении диаграмм расчетных сопротивлений грунта на уровне основания сваи (рис. 13) и графиков, представленных ранее (рис. 11), наблюдается сходство в диаграммах и их значениях. Однако существуют некоторые отличия. Экспериментальные диаграммы отражают существенно больший угол наклона, который указывает на более интенсивное увеличение несущей способности по глубине. Диаграммы, построенные по данным СП 24.13330, имеют чрезмерные участки, отражающие линейную зависимость увеличения несу- 


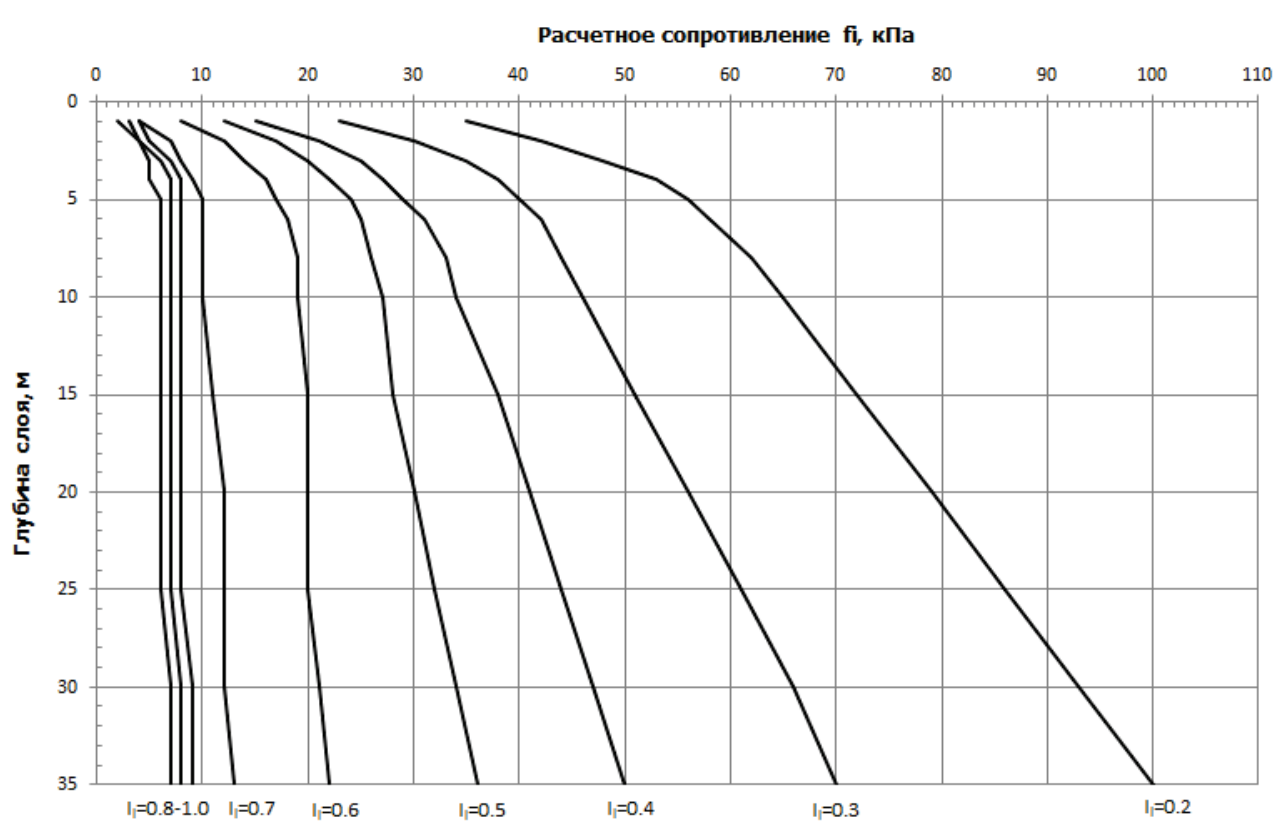

Pис. 12. Расчетные диаграмлы значений $f_{i}$ для пылевато-глинистых грунтов

Fig. 12. Pile shaft resistance for clays of various plasticity versus depth of penetration

щей способности по глубине, что представляется не соответствующим реальности.

К некоторым недостаткам методики СП можно отнести следующее:

- Не смотря на серьезную научно-экспериментальную базу данной методики, в проектностроительной практике она является оценочной и уступает по достоверности результатов полевым и экспериментальным способам оценки несущей способности - статическому и динамическому зондированию, эталонному испытанию свай, и пр., хотя и является основной аналитической методикой при обосновании проектных решений в органах государственной экспертизы. Так, по мнению авторов [16, 27, 28], действительная несущая способность нередко превосходит величину, рассчитанную по рекомендациям СП (СНиП). Уточнить ее можно, испытывая пробные сваи статической нагрузкой. Однако из-за сложности таких испытаний выполнить их удается лишь после того, как проект уже выпущен и строители приступают к сооружению фундамента [29].

- Недостаток экспериментальных исследований и отсутствие каких-либо работ по совершенствованию данной методики с момента ее первой публикации в СНиП ІІ-Б.5-62 от 1962 г. сформировали мнение в профессиональной среде, что данная методика является скорей оценочной, чем расчетной, особенно при строительстве в регионах со специфическим формированием инженерно-геологических условий в областях речных дельт (особенно субаэральных), в районах распространения специфических грунтов, в горных районах с широким рас- пространением элювиально-делювиальных образований и пр.

- Данная методика не учитывает целый ряд существенных факторов (механических свойств грунтов, напряженно-деформированного состояния массива, историю образования грунтов, и пр.). Как было показано выше, характер работы забивной сваи в грунтовом массиве является сложным комплексным процессом, зависящим от множества различных нелинейных факторов и точно не может быть описан лишь двумя независимыми переменными - глубиной слоя и его консистенцией (или размером частиц для песчаных грунтов). Не учитываются гидрогеологические условия, водонасыщенность грунтов. Так, в водонасыщенных глинах и суглинках уплотнение происходит только в результате отжима воды из пор грунта - процесс, который протекает длительное время.

- Тем более не может не вызывать вопросов практически полностью линейная аппроксимация участков диаграмм (начиная с пятиметровой глубины) зависимостей расчетных сопротивлений $R$ и $f_{i}$ от глубины расположения сваи в грунте, т. е. $\varphi=$ const. Это не соответствует многочисленным экспериментальным диаграммам, на которых наблюдается снижение угла трения $\varphi$ с глубиной.

- Данная методика показывает хорошие результаты при расчете свай в песчаных грунтах средней плотности. Она не распространяется на рыхлые пески, плохо оценивает несущую способность слабых глинистых грунтов, не учитывает работу специфических грунтов. Также эта методика имеет ограничения по глубине 


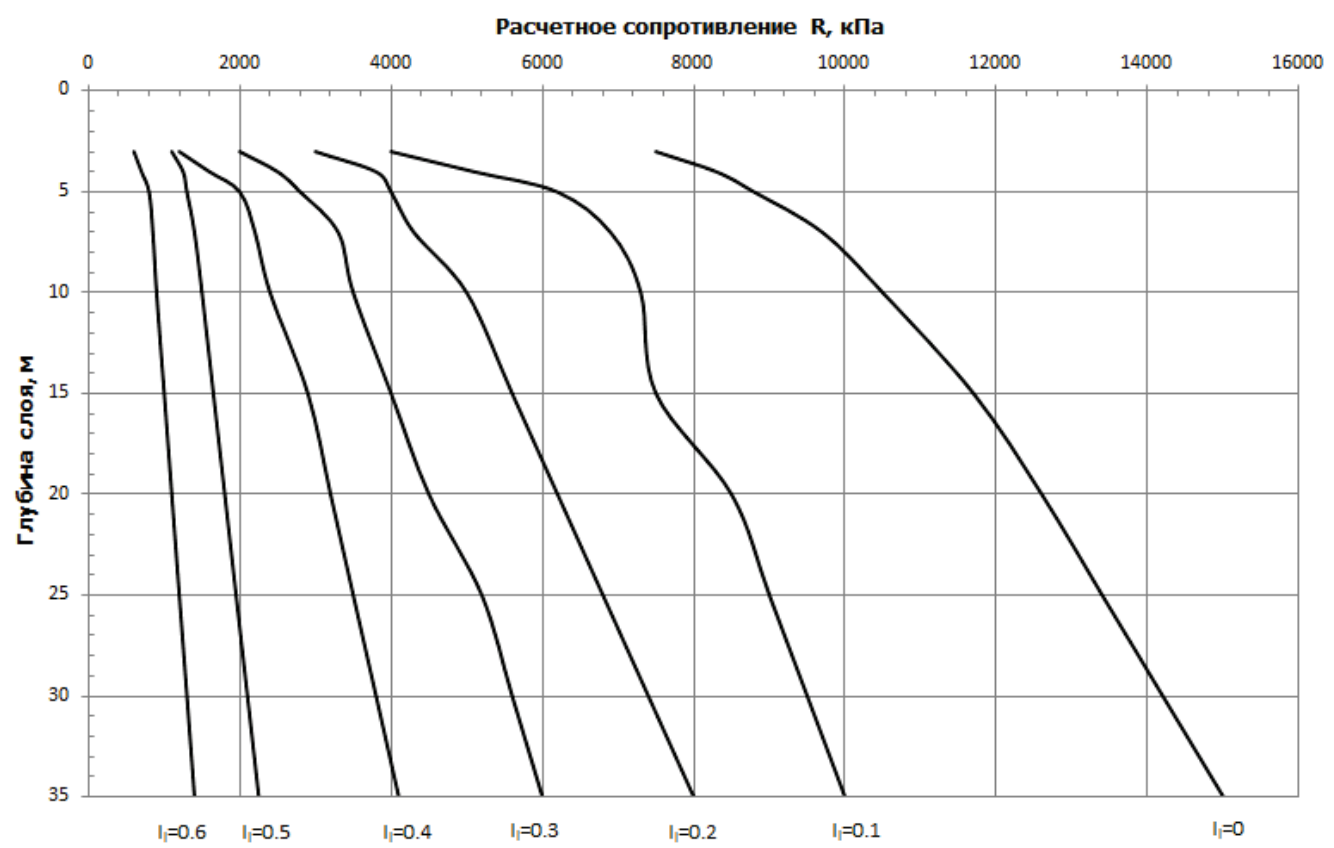

Pис. 13. Расчетные диаграллы значений сопротивления грунта в основании сваи

Fig. 13. Pile base resistance for clays of various plasticity versus depth of penetration

устройства свай - 35 м, хотя современные требования строительства нередко вынуждают прибегать при проектировании к устройству свайных фундаментов глубиной более 35 м.

- Поскольку функциональная зависимость между удельным сопротивлением грунта на боковой поверхности свай и ее длиной в песчаных и глинистых грунтах различна, то остаются вопросы к совмещению значений сопротивлений $R$ и $f_{i}$ у этих видов грунтов.

Bce это вынуждает участников строительного процесса прибегать к натурным методам определения несущей способности свай, даже при строительстве зданий и сооружений пониженных уровней ответственности, что напрямую отражается на показателях эффективности инвестиционных проектов, на их экономичности, на сроках проектирования и строительства.

Методика по Р.Л. Нордлунду [30]. Эта методика является полуэмпирической и широко используется в международной практике для расчета несущей способности сваи, расположенной в песчаных грунтах:

$$
\begin{aligned}
R & =R_{s}+R_{b}=\int_{0}^{L} f_{s}(z) p(z) d z+A_{s} q_{b}= \\
& =K C_{F} G_{v}^{\prime}(z) \sin (\delta)+\alpha_{T} N_{q}^{\prime} G_{v}^{\prime},
\end{aligned}
$$

где $K_{\delta}-$ коэффициент бокового давления грунта в $i$-м слое; $C_{F}-$ поправочный коэффициент; $G_{v}^{\prime}-$ эффективное напряжение в грунте в $i$-м слое; $\delta$ - угол трения между боковой поверхностью сваи и грунтом; $N_{q}^{\prime}$ - эмпирический коэффициент несущей способности; $\alpha_{t}-$ коэффициент геометрической жесткости сваи.
Метод М. Томлинсона [17]. Этот широко используемый метод при расчёте несущей способности учитывает параметры недренированного сопротивления сдвигу и, кроме этого, допускает, что сопротивление на боковой поверхности сваи не зависит от напряжения от пригрузки кровлей.

Несущая способность боковой поверхности сваи определяется выражением:

$$
R_{s}=\sum_{i=1}^{n} C_{a, i} A_{s, i}=\sum_{i=1}^{n} \propto_{i} C_{u j} A_{s,}
$$

где $C_{a, i}$ - сцепление в $i$-м слое; $A_{s}$ - площадь боковой поверхности сваи в пределах $i$-го слоя грунта; $\alpha_{i}-$ эмпирический коэффициент сцепления; $C_{u i}-$ недренируемое сцепление.

Несущая способность нижнего конца (пяты) сваи рассчитывается по формуле:

$$
R_{b}=q_{b} A_{b}=9 C_{u} A_{b},
$$

где $q_{b}$ - удельное сопротивление основания сваи; $A_{b}$ - площадь основания сваи; $C_{u}$ - недренированное сопротивление сдвигу (недренируемое сцепление).

\section{Сопоставительный анализ} экспериментально-аналитических определений несущей способности свай

Как было показано ранее, механизм работы свай в грунте является чрезвычайно сложным процессом, зависящим от множества факторов. Существующее множество аналитических методик расчетов дают весьма широкий спектр результатов, часто не сочетающихся друг с другом, а иногда они отличаются друг от друга в несколько раз [31, 32]. Целью данного исследования является проведение 
серии аналитических расчетов по определению несущей способности свай, анализ и сравнение их результатов с данными экспериментально-полевых испытаний свай С120.35. Для выполнения аналитических расчетов будут использованы описанные выше методики по Нордлунду и по Томлинсону, реализованные в программных комплексах RSPile (Rocscience) и GE05, а также эмпирический способ в соответствии с СП 24.13330. Экспериментальные (полевые) исследования несущей способности свай выполнялись в рамках работ по проектированию и строительству жилого комплекса в Люберецком районе Московской области. В качестве исходных данных для выполнения расчетов использовались материалы проектной документации на строительство жилого комплекса.

\section{Инженерно-геологические условия}

площадки строительства

Инженерно-геологические условия площадки строительства характеризуются как сложные. В основании фундаментов широко распространены специфические органоминеральные грунты сапропели, торфы и заторфованные глины.

В геоморфологическом отношении исследуемый участок расположен в пределах высокой поймы и первой надпойменной террасы поздненеоплейстоценового возраста (согласно общей стратиграфической шкалы МСК 2007) реки Пехорки притока реки Москвы. Поверхность изучаемой площадки относительно ровная, с общим уклоном в северо-западном направлении и абсолютными отметками 119,00-125,00 м. Переходы между элементами рельефа плавные. Рельеф осложнен наличием двух пересекающихся дренажных каналов. Природный эрозионно-аккумулятивный ре- льеф участка изменен вследствие хозяйственной деятельности человека.

В геологическом строении изучаемой территории на разведанную глубину до 80 м принимают участие следующие отложения: почвенно-растительный слой ( $\left.\mathrm{pQ}_{\mathrm{IV}}\right)$, современные аллювиальноозерные $\left(\mathrm{a}, 1 \mathrm{Q}_{\mathrm{IV}}\right)$ и озерно-болотные отложения $\left(\mathrm{l}, \mathrm{b} \mathrm{Q}_{\mathrm{IV}}\right)$, средне-верхненеоплейстоценовые аллювиально-озерные отложения $\left(\mathrm{a}, 1 \mathrm{Q}_{\mathrm{II}-\mathrm{II}}\right)$, верхнеюрские глины $\left(\mathrm{J}_{3}\right)$ и элювий известняков средне- и позднекаменноугольного возраста $\left(\mathrm{C}_{2}\right)$ и $\left(\mathrm{C}_{3}\right)$.

Грунтовые воды четвертичного водоносного горизонта встречены на глубинах 0,2-5,6 м.

На рис. 14 представлен один из характерных инженерно-геологических разрезов площадки строительства.

\section{Описание расчетных схем}

Фундаменты зданий жилого комплекса, в соответствии с проектной документацией, являются плитно-свайными, с шарнирным выпадающим узлом сопряжения свай. Сваи предусмотрены забивные инвентарные C120.35, длиной 12 м, квадратного сечения $350 \times 350$ мм, по ГОСТ 19804.2012.

Расчеты были выполнены по сопоставимым вариантам для свай, расположенных в разных местах в пределах одной площадки строительства, по следующим схемам:

1. Расчетный случай 1 (PC-1) - глубина погружения сваи 10,85 м. Основную часть свайного ствола занимает органоминеральный грунт (ИГЭ - 3) - сапропель;

2. Расчетный случай 2 (РС-2) - глубина погружения сваи около 12,0 м. При этом мощность слабого органоминерального слоя (ИГЭ - 3) является минимальной из трех случаев и составляет 1,49 м.

Таблица 2. Нормативные и расчетные значения прочностных и деформационных характеристик грунтов

Table 2. $\quad$ Soils strength and deformation parameters

\begin{tabular}{|c|c|c|c|c|c|c|c|c|}
\hline 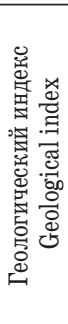 & 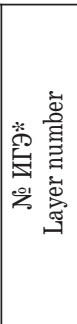 & $\begin{array}{c}\text { Наименование инженерно-геологического элемента (ИГЭ) } \\
\text { Soil description }\end{array}$ & 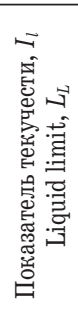 & 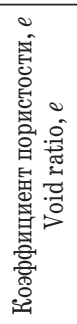 & 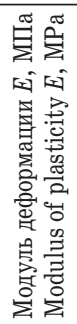 & 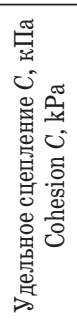 & 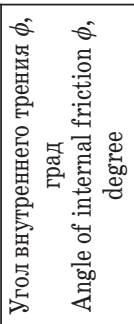 & 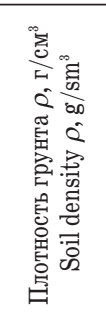 \\
\hline \multirow{3}{*}{ 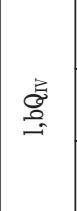 } & 3 & $\begin{array}{l}\text { сапропель } \\
\text { sapropel }\end{array}$ & 0,66 & 3,24 & 2 & 3 & 14 & 1,27 \\
\hline & 4 & $\begin{array}{l}\text { глина среднезаторфованная, мягкопластичная } \\
\text { peaty soft clays }\end{array}$ & 0,60 & 2,16 & 12 & 19 & 15 & 1,38 \\
\hline & 5 & $\begin{array}{l}\text { глина среднезаторфованная, тугопластичная } \\
\text { peaty hard clays }\end{array}$ & 0,31 & 2,33 & 11 & 19 & 12 & 1,35 \\
\hline \multirow{2}{*}{$\begin{array}{c}\frac{\Xi}{1} \\
\frac{\Xi}{\sigma} \\
\frac{\sigma}{\sigma}\end{array}$} & 6 & $\begin{array}{l}\text { песок пылеватый, средней плотности, влажный и водонасы- } \\
\text { щенный } \\
\text { silty sand, medium density, moist and water-saturated }\end{array}$ & - & 0,71 & 19 & 1 & 25 & $1,62 / 1,85$ \\
\hline & $7 \mathrm{a}$ & $\begin{array}{l}\text { песок мелкий, средней плотности, влажный и водонасыщен- } \\
\text { ный } \\
\text { fine sand, medium density, moist and water-saturated }\end{array}$ & - & 0,62 & 24 & 0 & 29 & $1,70 / 1,95$ \\
\hline
\end{tabular}

* - инженерно-геологические элеленты (ИГЭ) - цифры в кружках на рис. 14.

* - engineering-geological elements (EGE) - numbers in circles in Fig. 14. 


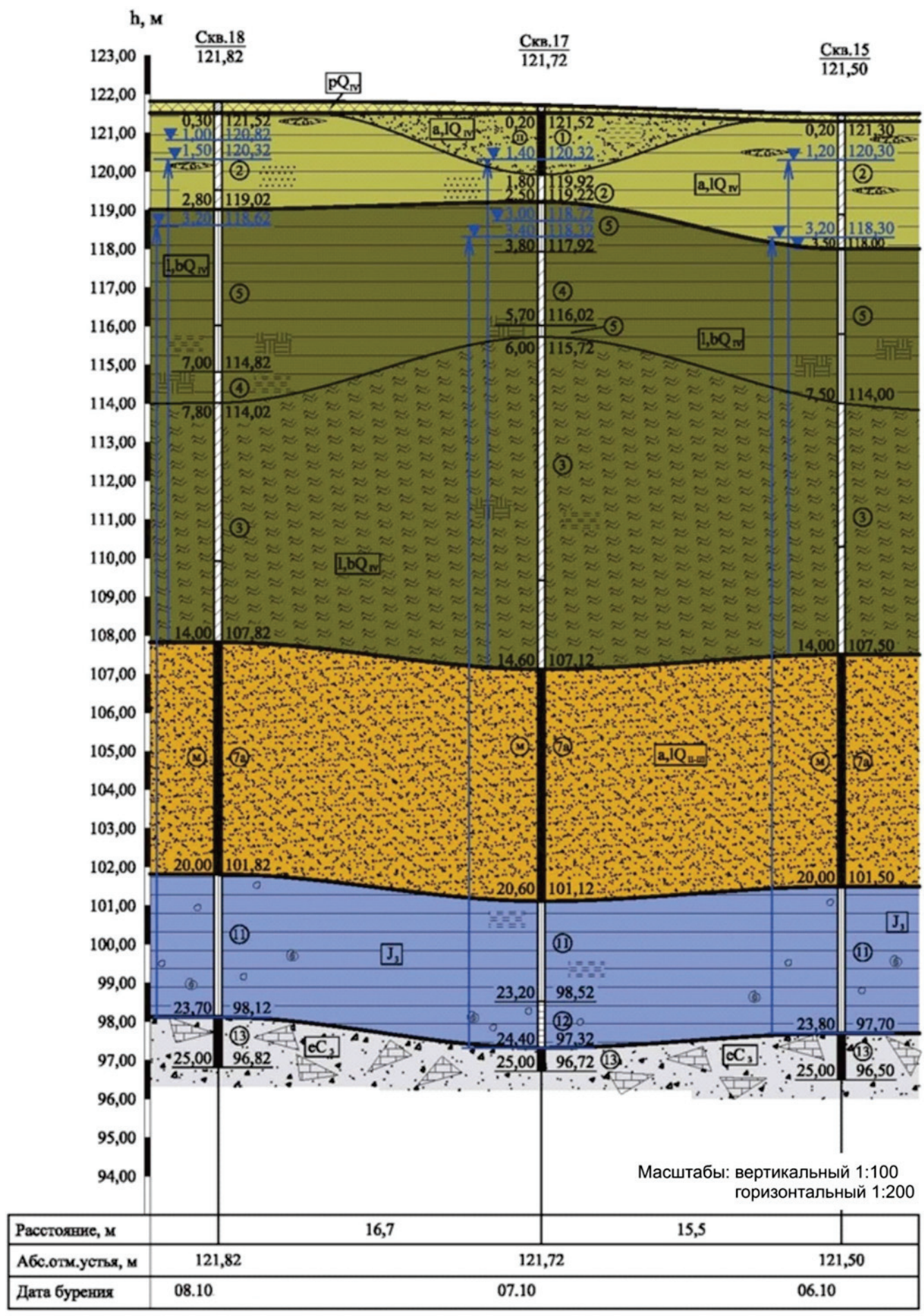

\section{$\begin{array}{llllllllll}\mathrm{pQIV} 1 & \text { (1) } 2 & \text { (2) } 3 & \text { (3) } 4 & \text { (4) } 5 & \text { (5) } 6 & \text { (7a) } 7 & \text { (11) } 8 & \text { (13) } 9\end{array}$}

Рис. 14. Инженерно-геологический разрез площадки строительства. 1 - почвенно-растительные, 2 - современные аллювиально-озерные (пески пылеватые), 3 - современные аллювиально-озерные (глина мягкопластичная), 4 - современные озерно-болотные (сапропель), 5 - современные озерно-болотные (глина заторфованная мягкопластичная), 6 - современные озерно-болотные (глина заторфованная тугопластичная), 7 - средне-верхненеоплейстоценовые аллювиально-озерные (пески мелкозернистые), 8 - верхнеюрские глины тугопластичной и полутвердой консистениии, 9 - элювий известняков средне-позднекаменноугольного возраcma

Fig. 14. Geology cross section of the construction site. 1 - soil-plant layer; 2 - modern alluvial-lacustrine soils (silty sands); 3 - modern alluvial-lacustrine soils (plastic clays); 4 - lake-marsh layer (sapropel); 5 - lake-marsh layer (peaty soft clays); 6 - lake-marsh layer (peaty hard clays); 7 - middle-upper Pleistocene alluvial-lacustrine soils (fine sands); 8 - upper Jurassic clays of low and intermediate plasticity; 9 - medium-late-carbon eluvium of limestone 

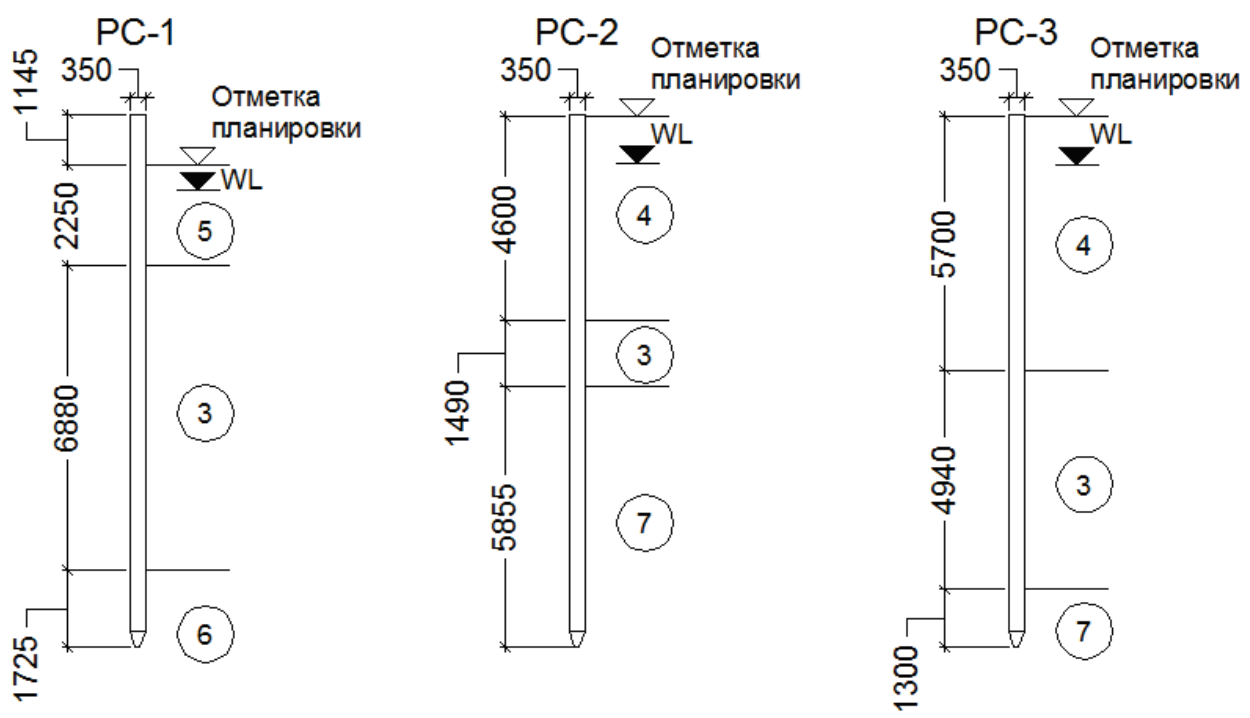

Pис. 15. Расчетная схема свайных фундаментов

Fig. 15. Piles analysis scheme

таблица 3. Результаты статических испытаний свай вдавливающей нагрузкой

Table 3. Results of pile loading tests

\begin{tabular}{|c|c|c|c|c|c|c|c|c|c|c|}
\hline 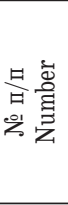 & 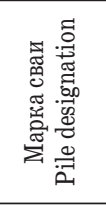 & 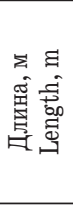 & 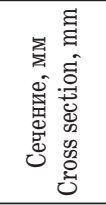 & 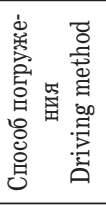 & 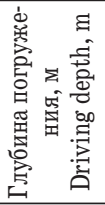 & 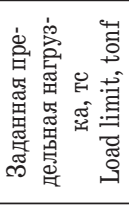 & 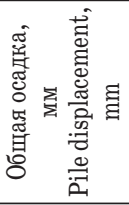 & 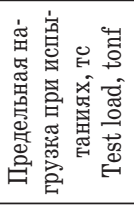 & 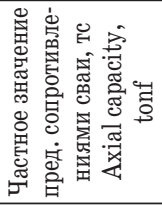 & 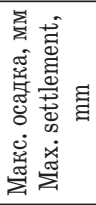 \\
\hline PC-1 & \multirow{3}{*}{$\mathrm{C} 120.35$} & \multirow{3}{*}{12,0} & \multirow{3}{*}{$350 \times 350$} & \multirow{3}{*}{ driving } & 10,855 & \multirow{3}{*}{115,0} & 12,37 & \multirow{3}{*}{115,0} & \multirow{3}{*}{115,0} & 12,37 \\
\hline PC-2 & & & & & 11,945 & & 5,65 & & & 5,65 \\
\hline PC-3 & & & & & 11,940 & & 10,15 & & & 10,15 \\
\hline
\end{tabular}

3. Расчетный случай 3 (РС-3) - глубина погружения сваи около 12,0 м. Данный вариант расположения сваи является промежуточным по доли слабого органоминерального грунта в общем массиве.

Расчетные схемы показаны на рис. 15 , свойства грунтов представлены в табл. 2. Для всех трех расчетных случаев были выполнены контрольные статические испытания свай.

\section{Статические испытаний свай}

Контрольные испытания свай проводились для подтверждения проектных расчетных значений несущей способности при строительстве жилого комплекса в Московской области, т. е. целью испытаний являлось не научно-экспериментальное исследование поведения забивных свай при нагружении и определение их максимальной несущей способности. Поэтому выявленная несущая способность была ограничена предельной вдавливающей нагрузкой, установленной проектировщиком.

Испытание забивной сваи осевой вдавливающей статической нагрузкой выполнялось в соответствии с требованиями $[25,26]$.

Железобетонные сваи длиной 12,0 м, сечением $350 \times 350$ мм погружены гидравлическим молотом
ННК-7А на глубины в соответствии с расчетной схемой. Фактическая нагрузка на сваи создавалась гидравлическим домкратом ДГН-200-160 и контролировалась манометром МПЗ-Уф 600.

Осадка свай измерялась двумя прогибомерами системы 6 ПАО с ценой деления 0,01 мм относительно реперной установки, жестко установленной на поверхности грунта около испытываемой сваи.

Наибольшая нагрузка на сваю со стабилизационной осадкой 0,1 мм за время выдержки каждой ступени нагрузки в два часа составила 115,0 т.

\section{Результаты и обсуждение}

Результаты расчета несущей способности свай, полученные различными методами, приведены в табл. 4.

Таблица 4. Сводные результаты расчетов несущей способности свай

Table 4. Summary results of piles bearing capacity calculations

\begin{tabular}{|l|c|c|c|}
\hline \multicolumn{1}{|c|}{ Методика/Calculation method } & PC-1, т & PC-2, т & PC-3, т \\
\hline CП 24.13330/SP 24.13330 & 37,6 & 70,77 & 45,54 \\
\hline RSPile & 107,2 & 90,5 & 86,0 \\
\hline GE05 & 75,9 & 45,7 & 84,1 \\
\hline Полевые испытания/Field tests & \multicolumn{3}{|c|}{115,0} \\
\hline
\end{tabular}


Как видно из табл. 4, расчет, выполненный на основе методики, приведенной в СП 24.13330.2011, не учитывает работу существенной части ствола сваи, т. к. она находится в зоне органоминеральных специфических грунтов, для которых не нормируется боковое сопротивление. Однако даже если сделать расчет на условное расположение (слабых) глинистых грунтов в зоне этих участков сваи, значение несущей способности сваи увеличится совсем незначительно.

Методика Р. Нордлунда, реализованная в программе RSPile, показала наиболее близкий результат с данными статических испытаний. Стоит еще раз отметить, что данная методика учитывает и физические, и механические характеристики грунтов, без рассмотрения их состава и строения, т. е. область использования данной методики не ограничивается ни по типу, ни по разновидности слагающих толщу грунтов.

Высокие значения несущей способности по результатам полевых статических испытаний свай могут объясняться повышенным восприятием внешней нагрузки нижними частями свай. Такое распределение усилий в свае и уровней сопротивления грунта (как это было показано в начале статьи) недооценивается действующими расчетными методиками.

Большие расхождения данных испытаний с аналитическими методиками (особенно с методикой СП) подтверждают тезис о несовершенстве предложенных моделей.

\section{Заключение}

Факторы, влияющие на несущую способность свай, имеют сложный характер взаимодействия и предопределяют комплексный механизм работы сваи в грунте, не поддающийся строгому математическому описанию. Существующие расчетные схемы и модели [33], в том числе базирующиеся на них численные методики, имеют существенные расхождения в результатах.

Из-за большого многообразия грунтовых условий действующие нормы не в состоянии предло-

\section{СПИСОК ЛИТЕРАТУРЫ}

1. A Nonlinear Approach for Time-Dependent Settlement Analysis of a Single Pile and Pile Groups / S. Feng, X. Li, F. Jiang, L. Lei, Z. Chen // Soil Mechanics and Foundation Engineering. - 2017. V. 54. - Iss. 1. - P. 7-16.

2. A calculation approach for nonlinear load-settlement curve of single tapered pile and tapered pile group / J. Li, H. Chen, L. Li, X. Cao // Journal of Harbin Institute of Technology. - 2017. V. 49. - P. 102-109. DOI: 10.11918/j.issn.0367-6234.201702001.

3. Xia Z.-Q., Zou J.-f. Simplified Approach for Settlement Analysis of Vertically Loaded Pile // Journal of Engineering Mechanics. 2017. - V. 143. - Iss. 11. DOI: 10.1061/(ASCE) EM.1943-7889. 0001334

4. Settlement calculation of pile foundations with elevated caps by energy method / M. Zhao, Y. Yang, P. Yin, J. Long // Journal of Central South University (Science and Technology). - 2015. - V. 46. Iss. 2. - P. 670-675. DOI: 10.11817/j.issn.1672-7207.2015.02.040 жить единую методику определения несущей способности грунтов с достаточно высокой степенью точности приближения к фактическим данным, получаемым при натурных испытаниях.

Использование методики по определению несущей способности, согласно СП 24.13330, применимо в простых инженерно-геологических условиях и преимущественно для грунтов осадочного происхождения. В целом эта методика имеет низкий уровень достоверности результатов, особенно для слабых пылевато-глинистых грунтов. К тому же, как это было показано, в этой методике ярко прослеживается схожесть значений расчетных сопротивлений с данными, полученными В.Г. Березанцевым, F. Kulhawy для песчаных грунтов, а не для глинистых, т. е. ее работоспособность применительно к тонкодисперсным грунтам требует дополнительных исследований.

Мнение о возможности расчета свай с помощью численных методик также требует верификации полученных результатов на основе сравнения с натурными испытаниями.

Применение в отечественной практике западных методик является затруднительным в силу отличающихся стандартов определения исходных характеристик грунтов на этапе инженерно-геологических изысканий.

Отсутствие достоверных, отработанных на практике, методов расчета несущей способности свай экономически предопределяет необходимость использования не научно обоснованных методов, а строительных (полевых) способов, не эффективных по затратам математических или численных расчетов, а дорогостоящих полевых определений (натурных замеров) несущей способности свай, на предпроектных этапах инженерных изысканий. А при отсутствии материалов полевых испытаний проектировщику приходится перезакладываться на незнание, что существенно увеличивает сметную стоимость фундаментов.

Такая ситуация обуславливает острую необходимость дальнейших научно-экспериментальных исследований в этой области.

5. Ободовский А.А. Проектирование свайных фундаментов. - М.: Стройиздат, 1977. - 112 с.

6. СП 24.13330.2011 Свайные фундаменты. - М.: Минрегион России, 2011; измен. № 1 приказ Министерства строительства и жилищно-коммунального хозяйства Российской Федерации (Минстрой России) от 3 декабря 2016 г. N 885/пр.

7. Пилягин А.В. Проектирование оснований и фундаментов зданий и сооружений. 3-е изд., переработанное и дополненное. М.: Изд-во АСВ, 2017. - 398 с.

8. Aziz H.Y., Maula B.H. Estimation of negative skin friction in deep pile foundation using the practical and theoretically approaches // Journal of Engineering and Applied Sciences. - 2018. V. 13. - № 10. - P. 3340-3349.

9. Miller T., Lee C. Novel pile design for multi-level car park above twin rail tunnels // Australian geomechanics. - 2017. - V. 52. № 44. - P. 15-27.

10. Zhang Y. Estimation of Free Penetration of Steel Pile and Numerical Simulation // Ship Building of China. - 2017. - V. 58. - P. 547-556. 
11. Нуждин Л.В., Михайлов В.С. Численное моделирование свайных фундаментов в расчетно-аналитическом комплексе SCAD Office // Вестник ПНИПУ. Строительство и архитектура. 2018. - № 1. - C. 5-18. DOI: 10.15593/2224-9826/2018.1.01

12. Луга А.А. Некоторые вопросы предельных состояний свайных фундаментов. - М.: б.и., 1959. - 50 с. (Сообщение: лаборатория оснований и фундаментов опор мостов. № 148).

13. Грунтоведение / под ред. В.Т. Трофимова. - М.: Изд-во МГУ, $2005 .-798 \mathrm{c}$.

14. The experience of building buildings on Jurassic clays in Moscow / R.S. Ziangirov, Yu.P. Kryilov, I.A. Nikolaev I.A. // Soil Mechanics and Foundation Engineering. - 2000. - № 3. - P. 76-80.

15. Солдатов Б.А. Исследование несущей способности забивных висячих свай и свайных фундаментов в элювиальных глинистых грунтах Среднего Урала: автореф. дис. ... канд. техн. наук. - Свердловск, 1972. - 24 с.

16. Долматов Б.И. Особенности работы свайных фундаментов в условиях слабых грунтов. - М.: Трест «Оргсельстрой», 1966. $6 \mathrm{c.}$

17. Tomlinson M.J. Foundation Design and Construction. - London: Longman Scientific and Technical, 1986. - 842 p.

18. Burland J.B. Shaft Friction of Piles in Clay - a Simple Fundamental Approach // Ground Engineering. - 1973. - V. 6 (3). P. 30-42.

19. Martin J., Budden D., Norman S. Pile tests to justify higher adhesion factors in London Clay // Proc. of the Institution of Civil Engineers - Geotechnical Engineering. - 2016. - V. 169. Iss. 2. - P. 121-128.

20. Грутман М.С. Свайные фундаменты. - Киев: Будівельник, 1969. - $193 \mathrm{c}$.

21. Tomlinson, M. J. The adhesion of piles in stiff clays // Proc. 4th Int. Conf. Soil Mech. Found. Eng. - England, 1957. - V. 2. P. 66-71.

22. Relationship between Ko and overconsolidation ratio: a theoretical approach / V. Sivakumar, I.G. Doran, J. Graham, T. Navaneethan // Geotechnique. - 2001. - V. 52. - № 3. - P. 225-230.
23. Григорян А.А. Расчет несущей способности сваи // Проблемы свайного фундаментостроения: Труды VI международной конференции. - М., 1998. - Т. 1 - С. 37-42.

24. Kulhawy F.H. Limiting tip and side resistance, fact or fallacy // Symposium on Analysis and Design of Pile Foundations. Proceedings. - San Francisco, 1984. - P. 80-98.

25. Kerisel J. Deep Foundations in Sands: Variation of Ultimate Bearing Capacity with Soil Density, Depth, Diameter and Speed // Soil Mechanics and Foundation Engineering: Proc. of the $5^{\text {th }}$ International Conference. - Paris, 1961. - V. II. - P. 73-84.

26. Bjerrum L. Problems of Soil Mechanics and Construction on Soft Clays and Structurally Unstable Soils / / Soil Mechanics and Foundation Engineering: Proc. of the $8^{\text {th }}$ International Conference. Moscow, 1973. - V. 3. - P. 111-159.

27. Свайные фундаменты / Н.М. Глотов, А.А. Луга, К.С. Силин, К.С. Завриев. - М.: Транспорт, 1975. - 432 с.

28. Долматов Б.И., Лапшин Ф.К. Оценка несущей способности свай при массовом их применении // Совещание-семинар по обмену опытом проектирования и возведения свайных фундаментов. - М., 1966. - С. 2-6.

29. Силин К.С., Глотов Н.М., Завриев К.С. Проектирование фундаментов глубокого заложения. - М.: Транспорт, 1981. - 252 с.

30. Nordlund R.L. Point bearing and shaft friction of piles in sand // $5^{\text {th }}$ Annual Short Course on the Fundamentals of Deep Foundation Design. Proc. - Missouri-Rolla, 1979.

31. Кургузов К.В., Фоменко И.К. Сравнение методик расчета несущей способности свай // Стратегия развития геологического исследования недр: настоящее и будущее (к 100-летию МГРИРГГРУ): Материалы Международной научно-практической конференции. - М., 2018. - Т. 2. - С. 254-255.

32. Jegandan S., Thusyanthan N.I., Robert D.J. Axial bearing capacity of driven piles in accordance with API and DNV // 7th International Conference Offshore Site Investigation and Geotechnics.- UK, September 2012. - P. 525-532.

Поступила 23.11.2018 2.

\section{Информация об авторах}

Kургузов $\boldsymbol{K}$.B., аспирант кафедры инженерной геологии гидрогеологического факультета Российского государственного геологоразведочного университета им. С. Орджоникидзе.

Фоменко И.К., доктор геолого-минералогических наук, профессор кафедры инженерной геологии гидрогеологического факультета Российского государственного геологоразведочного университета им. С. Орджоникидзе.

Сироткина O.H., кандидат геолого-минералогических наук, старший научный сотрудник кафедры динамической геологии геологического факультета Московского государственного университета им. Ломоносова. 
UDK 624.154.1

\title{
CALCULATION OF DRIVEN PILE BEARING CAPACITY. ANALYTICAL METHODS AND ISSUES
}

\author{
Konstantin V. Kurguzov', \\ kurgusov@yandex.ru \\ Igor K. Fomenko', \\ ifolga@gmail.com \\ Olga N. Sirotkina², \\ onsirotkina@gmail.com \\ 1 Russian State Geological Prospecting University, \\ 23, Miklukho-Maklay street, Moscow, 117997, Russia. \\ 2 Lomonosov Moscow State University, \\ GSP-1, Leninskie Gory, Moscow, 119991, Russia.
}

The relevance. Deep foundations, especially piled ones, is a common technical solution for various buildings and structures. These types of foundations are used in unfavorable engineering geology conditions with weak soils, when the external load should be transferred to the strong deep laying stratum. This type of foundations is known as well as more reliable shallow foundations, as it decreases soil settlements and uneven deformations. Although pile foundations are used on a broad scale all over the world the preciseness of analytical evaluations (or calculations) of bearing capacity is not even close to the desired level yet.

The main aim of the research is to carry out a series of analytical calculations through application of various methods and series of field practical tests of the displacement piles.

Objects. The initial data for the research was working documentation and field practical piles tests that were held as a part of construction project of a multifunctional, multistorey complex in Moscow region.

Methods. Analytical calculations of bearing capacity of piles were performed with application of various methods such as broadly known Tomlinson and Nordlund methods and the method proposed in Russian standard - SP 24.13330.

Results. Pile to soil interaction is a very complex process that depends on numerous factors. The mechanics of this interaction could hardly be mathematically modeled these days, which predefines the necessity of using engineering, empirical or half-empirical, analytical methods. The performed comparison between the analytical calculations and the practical tests results has shown substantial discrepancy. Besides, the research shown a straight correlation between engineering geology complexity and the calculations results discrepancy level.

Key words:

Pile bearing capacity calculation, pile to soil interaction, driven piles, friction piles, pile analysis methods, static loading tests of a pile.

\section{REFERENCES}

1. Feng S., Li X., Jiang F., Lei L., Chen Z. A Nonlinear Approach for Time-Dependent Settlement Analysis of a Single Pile and Pile Groups. Soil Mechanics and Foundation Engineering, 2017, vol. 54, Iss. 1, pp. 7-16.

2. Li J., Chen H., Li L., Cao X. A calculation approach for nonlinear load-settlement curve of single tapered pile and tapered pile group. Journal of Harbin Institute of Technology, 2017, vol. 49, pp. 102-109. DOI: 10.11918/j.issn.0367-6234.201702001.

3. Xia Z.-Q., Zou J.-f. Simplified Approach for Settlement Analysis of Vertically Loaded Pile. Journal of Engineering Mechanics, 2017, vol. 143, Iss. 11, DOI: 10.1061/(ASCE) EM.1943-7889. 0001334

4. Zhao M., Yang Y., Yin P., Long J. Settlement calculation of pile foundations with elevated caps by energy method. Journal of Central South University (Science and Technology), 2015, vol. 46, Iss. 2, pp. 670-675. DOI: 10.11817/j.issn.1672-7207.2015.02.040

5. Obodovskiy A.A. Proektirovanie svaynykh fundamentov [Design of pile foundations]. Moscow, Stroyizdat Publ., 1977. 112 p.

6. SP 24.13330.2011 Svaynye fundamenty [Pile foundations]. Moscow, Ministry of Regional Development of Russia, 2011. p. 85.

7. Pilyagin A.V. Proektirovanie osnovaniy i fundamentov zdaniy $i$ sooruzheniy [Design of foundations and foundations of buildings and structures]. Moscow, ASV Publ., 2017. 398 p.

8. Aziz H.Y., Maula B.H. Estimation of negative skin friction in deep pile foundation using the practical and theoretically approaches. Journal of Engineering and Applied Sciences, 2018, vol. 13 , no. 10 , pp. $3340-3349$.
9. Miller T., Lee C. Novel pile design for multi-level car park above twin rail tunnels. Australian geomechanics, 2017, vol. 52, no. 44, pp. $15-27$.

10. Zhang Y. Estimation of Free Penetration of Steel Pile and Numerical Simulation. Ship Building of China, 2017, vol. 58, pp. 547-556.

11. Nuzhdin L.V., Mikhaylov V.S. Numerical modeling of pile foundations in the structural analysis software SCAD Office. Bulletin of PNRPU. Construction and Architecture, 2018, no. 1, pp. 5-18. In Rus. DOI: 10.15593/2224-9826/2018.1.01

12. Luga A.A. Nekotorye voprosy predelnykh sostoyaniy svaynykh fundamentov [Some issues of the limit states of pile foundations]. Moscow, $1959.50 \mathrm{p}$.

13. Gruntovedenie [Pedology]. Ed. by V.T. Trofimov. Moscow, MGU Publ., 2005. 798 p.

14. Ziangirov R.S., Kryilov Yu.P., Nikolaev I.AThe experience of building buildings on Jurassic clays in Moscow. Soil Mechanics and Foundation Engineering, 2000, no. 3, pp. 76-80.

15. Soldatov B.A. Issledovanie nesushchey sposobnosti zabivnykh visyachikh svay i svaynykh fundamentov v elyuvialnykh glinistykh gruntakh Srednego Urala. Avtoreferat Dis. kand. nauk [Investigation of bearing capacity of hammered piles and pile foundations in eluvial clayey soils of the Middle Urals. Cand. Diss. Abstract]. Sverdlovsk, 1972. $24 \mathrm{p}$.

16. Dolmatov B.I. Osobennosti raboty svaynykh fundamentov v usloviyakh slabykh gruntov [Features of pile foundations in conditions of weak soils]. Moscow, Trest «Orgselstroy» Publ., 1966. $6 \mathrm{p}$. 
17. Tomlinson M.J. Foundation Design and Construction. London, Longman Scientific and Technical, 1986. 842 p.

18. Burland J.B. Shaft Friction of Piles in Clay - a Simple Fundamental Approach. Ground Engineering, 1973, vol. 6 (3), pp. 30-42.

19. Martin J., Budden D., Norman S. Pile tests to justify higher adhesion factors in London Clay. Proc. of the Institution of Civil Engineers - Geotechnical Engineering, 2016, vol. 169, Iss. 2, pp. 121-128.

20. Grutman M.S. Svaynye fundamenty [Pile foundations]. Kiev, Budivelnik Publ., 1969. 193 p.

21. Tomlinson M.J. The adhesion of piles in stiff clays. Proc. $4^{\text {th }}$ Int Conf. Soil Mech. Found. Eng. England, 1957. Vol. 2. pp. 66-71.

22. Sivakumar V., Doran I.G., Graham J., Navaneethan T. Rela tionship between $\mathrm{Ko}$ and overconsolidation ratio: a theoretical approach. Geotechnique, 2001, vol. 52, no. 3, pp. 225-230.

23. Grigoryan A.A. Raschet nesushchey sposobnosti svay [Calculation of bearing capacity of piles]. Problemy svaynogo fundamentostroeniya. Trudy VI Mezhdunarodnoy konferentsii [Problems of pile foundation construction. Proc. of the VI International Conference]. Moscow, 1998. Vol. 1, pp. 37-42.

24. Kulhawy F.H. Limiting tip and side resistance, fact or fallacy. Symposium on Analysis and Design of Pile Foundations. Proc. San Francisco, 1984. pp. 80-98.

25. Kerisel J. Deep Foundations in Sands: Variation of Ultimate Bearing Capacity with Soil Density, Depth, Diameter and Speed. Soil Mechanics and Foundation Engineering. Proc. of the $5^{\text {th }}$ International Conference. Paris, 1961. Vol. II, pp. 73-84.

26. Bjerrum L. Problems of Soil Mechanics and Construction on Soft Clays and Structurally Unstable Soils. Soil Mechanics and Foundation Engineering. Proc. of the $8^{\text {th }}$ International Conference. Moscow, 1973. Vol. 3, pp. 111-159.
27. Glotov N.M., Luga A.A., Silin K.S., Zavriev K.S. Svaynye fundamenty [Pile foundations]. Moscow, Transport Publ., 1975. 432 p.

28. Dolmatov B.I., Lapshin F.K. Otsenka nesushchey sposobnosti svay pri massovom ikh primenenii [Evaluation of the bearing capacity of piles for mass application]. Soveshchanie-seminar po obmenu opytom proektirovaniya i vozdeystviya svaynykh fundamentou [Meeting-seminar on the exchange of experience in the design and erection of pile foundations]. Moscow, 1966. pp. 2-6.

29. Silin K.S., Glotov N.M., Zavriev K.S. Proektirovanie fundamentov glubokogo zalozheniya [Design of deep foundations]. Moscow, Transport publ., 1981. $252 \mathrm{p}$.

30. Nordlund R.L. Point bearing and shaft friction of piles in sand. $5^{\text {th }}$ Annual Short Course on the Fundamentals of Deep Foundation Design. Proc. Missouri-Rolla, 1979.

31. Kurguzov K.V., Fomenko I.K. Sravnenie metodik rascheta nesushchey sposobnosti svay [Comparison of methods for calculating the bearing capacity of piles]. Strategiya razvitiya geologichesskogo issledovaniya nedr: nastoyashchee i budushchee ( $k$ 100-letiyu MGRI-RGGRU). Materialy Mezhdunarodnoy nauchno-prakticheskoy konferentsii [Strategy for development of geological exploration of mineral resources: the present and the future (to the $100^{\text {th }}$ anniversary of MGRI-RGGRU). Proc. of the International Scientific and Practical Conference]. Moscow, 2018. Vol. 2, pp. $254-255$.

32. Jegandan S., Thusyanthan N.I., Robert D.J. Axial bearing capacity of driven piles in accordance with API and DNV. $7^{\text {th }}$ International Conference Offshore Site Investigation and Geotechnics. London, UK, 12-14 September 2012. pp. 525-532.

Received: 23 November 2018.

\section{Information about the authors}

Konstantin V. Kurguzov, postgraduate student, Russian State Geological Prospecting University.

Igor K. Fomenko, Dr. Sc., professor, Russian State Geological Prospecting University.

Olga N. Sirotkina, Cand. Sc., senior scientific researcher, Lomonosov Moscow State University. 